University of Nebraska - Lincoln

DigitalCommons@University of Nebraska - Lincoln

Adam Liska Papers

Biological Systems Engineering

$11-14-2018$

\title{
Water, Energy, and Carbon Footprints of Bioethanol from the U.S. and Brazil
}

\author{
Mesfin Mekonnen \\ University of Nebraska - Lincoln, mmekonnen2@unl.edu \\ Thiago L. Romanelli \\ University of São Paulo \\ Chittaranjan Ray \\ University of Nebraska-Lincoln, cray@nebraska.edu \\ Arjen Y. Hoekstra \\ University of Twente, a.y.hoekstra@utwente.nl \\ Adam Liska \\ University of Nebraska - Lincoln, aliska2@unl.edu
}

See next page for additional authors

Follow this and additional works at: https://digitalcommons.unl.edu/bseliska

Part of the Atmospheric Sciences Commons, Bioresource and Agricultural Engineering Commons, Climate Commons, Environmental Indicators and Impact Assessment Commons, Natural Resources Management and Policy Commons, Other Civil and Environmental Engineering Commons, Other Earth Sciences Commons, and the Other Environmental Sciences Commons

Mekonnen, Mesfin; Romanelli, Thiago L.; Ray, Chittaranjan; Hoekstra, Arjen Y.; Liska, Adam; and Neale, Christopher M. U., "Water, Energy, and Carbon Footprints of Bioethanol from the U.S. and Brazil" (2018). Adam Liska Papers. 32.

https://digitalcommons.unl.edu/bseliska/32

This Article is brought to you for free and open access by the Biological Systems Engineering at DigitalCommons@University of Nebraska - Lincoln. It has been accepted for inclusion in Adam Liska Papers by an authorized administrator of DigitalCommons@University of Nebraska - Lincoln. 


\section{Authors}

Mesfin Mekonnen, Thiago L. Romanelli, Chittaranjan Ray, Arjen Y. Hoekstra, Adam Liska, and Christopher M. U. Neale 


\title{
Water, Energy, and Carbon Footprints of Bioethanol from the U.S. and Brazil
}

\author{
Mesfin M. Mekonnen, ${ }^{1}$ Thiago L. Romanelli, ${ }^{2}$ \\ Chittaranjan Ray, ${ }^{3}$ Arjen Y. Hoekstra, ${ }^{4,5}$ Adam J. Liska, ${ }^{6}$ \\ and Christopher M.U. Neale ${ }^{1}$
}

\author{
1 Robert B. Daugherty Water for Food Global Institute, \\ University of Nebraska, Lincoln, Nebraska 68583, United States \\ 2 Department of Biosystems Engineering, College of Agriculture \\ "Luiz de Queiroz" (ESALQ), University of São Paulo, \\ São Paulo 13418-900, Brazil \\ 3 Nebraska Water Center, Robert B. Daugherty Water for Food Global \\ Institute, University of Nebraska, Lincoln, Nebraska 68583, United States \\ 4 Twente Water Centre, University of Twente, P.O. Box 217, \\ 7500 AE Enschede, The Netherlands \\ 5 Institute of Water Policy, Lee Kuan Yew School of Public Policy, \\ National University of Singapore, 469A Bukit Timah Road, 259770, Singapore \\ 6 Department of Biological Systems Engineering, University of Nebraska-Lincoln, \\ Lincoln, Nebraska 68583, United States \\ Corresponding author - M. M. Mekonnen, tel 402-472-5392; email mmekonnen2@unl.edu
}

ORCID: Mesfin M. Mekonnen: 0000-0002-3573-9759

\begin{abstract}
Driven by biofuel policies, which aim to reduce greenhouse gas (GHG) emissions and increase domestic energy supply, global production and consumption of bioethanol have doubled between 2007 and 2016, with rapid growth in corn-based bioethanol in the U.S. and sugar cane-based bioethanol in Brazil. Advances in crop yields, energy use efficiency in fertilizer production, biomass-to-ethanol conversion rates, and energy efficiency in ethanol production have improved the energy balance and GHG emission reduction potential of bioethanol. In the current study,
\end{abstract}


the water, energy, and carbon footprints of bioethanol from corn in the U.S. and sugar cane in Brazil were assessed. The results show that U.S. corn bioethanol has a smaller water footprint ( $541 \mathrm{~L}$ water/L bioethanol) than Brazilian sugar cane bioethanol (1115 L water/L bioethanol). Brazilian sugar cane bioethanol has, however, a better energy balance (17.7 MJ/L bioethanol) and smaller carbon footprint (38.5 $\mathrm{g} \mathrm{CO}_{2} \mathrm{e} / \mathrm{MJ}$ ) than U.S. bioethanol, which has an energy balance of $11.2 \mathrm{MJ} / \mathrm{L}$ bioethanol and carbon footprint of $44.9 \mathrm{~g} \mathrm{CO}_{2} \mathrm{e} / \mathrm{MJ}$. The results show regional differences in the three footprints and highlight the need to take these differences into consideration to understand the implications of biofuel production for local water resources, net energy production, and climate change mitigation.

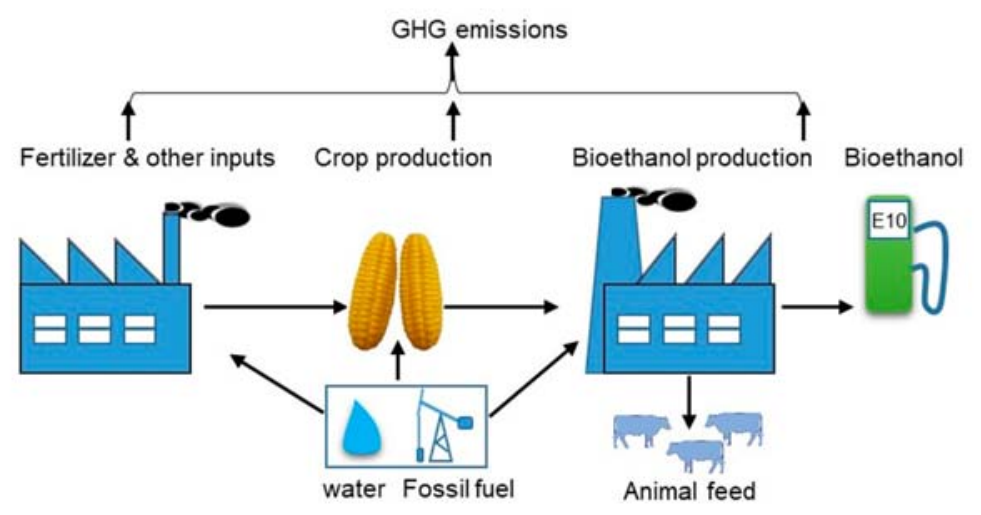

\section{Introduction}

In the last few decades, a number of countries have been promoting biofuels as a means to reduce greenhouse gas (GHG) emissions, secure domestic energy supply, and promote rural economic development. ${ }^{1}$ Between 2007 and 2016, global bioethanol production grew 2 -fold, ${ }^{2}$ mostly as a result of subsidized biofuel programs. Particularly, the U.S., Brazil, and the European Union (EU) are major drivers behind the move toward more biofuels in their energy mix. The U.S. has committed to increase biofuel (including ethanol, biodiesel, and advanced biofuels) 3-fold by 2022 from its 2010 level under its Renewable Fuels Standard program; ${ }^{3}$ but the vast majority of this mandated increase would have to come from cellulosic ethanol, which has largely failed to materialize. In Brazil, the National Alcohol Program (Pró-Álcool) launched mid 1970s is the primary program promoting biofuel, characterized by a number of incentives including tax exemptions, guaranteed purchase of ethanol, and a mandatory blending of $18-27 \%$ of ethanol in gasoline. ${ }^{4}$

Brazil was the largest bioethanol producer in the world until the U.S. surpassed it in 2006. 2,5 The expansion of bioethanol production in both countries was significant, with an 88-fold increase in the U.S. and 8-fold increase in Brazil from 1980 to 2016.2,5 The U.S. is now the world's largest producer of bioethanol, accounting for $58 \%$ of the global production in 2016 , followed by Brazil with 
$27 \% .^{2}$ The main source of bioethanol production in the U.S. is corn, in Brazil is sugar cane, and in Europe is sugar beet.

The fast development of biofuel production has raised important questions regarding its actual benefits in reducing GHG emissions and its effects on food prices, food security, biodiversity, water quality, and water depletion. ${ }^{6,7}$ In particular, there has been an ongoing debate on whether bioethanol from corn provides a positive energy balance or not, ${ }^{8-11}$ but this debate was largely settled by a 2006 Science article. ${ }^{12}$

Several studies were conducted over the last few decades on the energy balance and GHG emission reduction of corn bioethanol. In particular the earlier studies ${ }^{9,13-17}$ concluded that bioethanol production from corn requires more energy than that derived from the bioethanol, thus resulting in a negative energy balance (for a detailed literature review, see Liska and Cassman ${ }^{18}$ ). More recent studies, in particular those from the U.S. Department of Agriculture ${ }^{19,20}$ and others, 11,12,21,22 concluded that bioethanol from corn has a positive energy balance and could help reduce GHG emissions and secure domestic energy supply. The opposing conclusions mainly follow from differences in system boundaries, assumptions, and changes in the industry over time. ${ }^{7,23}$ The studies also differ in the extent of including upstream energy use (e.g., energy to produce farm machinery), and in terms of accounting for the coproduct energy credit. The earlier studies generally tend to overestimate the energy use because they do not include recent increases in the energy efficiency of the different production systems, particularly biorefinery efficiency, that occurred in later years with industry expansion. ${ }^{24}$ Over the years, the energy intensity of farm inputs such as fertilizers, direct energy use per unit of crop produced, crop yield, and the biomass-toethanol conversion rate have improved significantly. ${ }^{11,19,25}$ Total (direct plus indirect) energy input per unit of corn produced has decreased by $25 \%$ between 1990 and 2010. ${ }^{19}$ During the same period, corn yields have increased by $35 \%$. Furthermore, ethanol yields per unit of corn have increased by $26 \%$ between 1980 and 2008. ${ }^{25}$ These improvements in the energy efficiency of farm production and bioethanol production is reflected in the positive energy balance found in more recent studies.

The potential benefit of biofuels in reducing GHG emissions is another highly debated topic. ${ }^{7}$ Several studies suggest that replacing fossil fuels by bioethanol will reduce GHG emissions. 11,12,21,26,27 According to Searchinger et al., ${ }^{28}$ these studies fail to account for the effect of indirect landuse changes (ILUC) on GHG emissions, thus overestimating the GHG emission saving when replacing fossil fuels by biofuels. Searchinger et al. ${ }^{28}$ concluded that if the GHG emissions related to ILUC from tropical deforestation are taken into account, corn-based bioethanol will nearly double GHG emissions instead of reducing them..$^{23}$ Fargione et al. ${ }^{29}$ came to similar findings, but for direct conversion of local grasslands. Both Fargione et 
al. ${ }^{29}$ and Searchinger et al. ${ }^{28}$ argue that biofuels are best made from crop residues instead of grains.

Agriculture is the major water user, accounting for $69 \%$ of the global water withdrawal from rivers, lakes, and groundwater in 2010, ${ }^{30}$ and $92 \%$ of humanity's water footprint. ${ }^{31}$ The recent increased interest in biofuels will further increase the competition over scarce water resources. Water consumption for producing crops for bioethanol production has thus become an important issue. The water footprint of bioethanol could have implications for these bioethanol programs. Relevant variables to be considered, for example, include the choice of feedstock, the intensity of fertilizer use and irrigation, the crop yields achieved, and the biomass-to-ethanol conversion efficiency. The water footprint (WF) quantifies the amount of water that is consumed and/or polluted in a final product, considered across the full supply chain. ${ }^{32}$ The WF consists of three components: the blue WF, which refers to the volume of surface water and groundwater consumed; the green WF, which measures the volume of rainwater consumed; and the gray WF, which refers to the volume of water that is required to assimilate pollutants. ${ }^{32}$ In case of the green and blue WF, water "consumption" refers to the amount of water that evaporates and is therefore not available for another use in the same catchment in the same time period. Several studies on the WF of biofuels have been conducted, where some focused on a single crop and specific country ${ }^{33,34}$ or several crops in a specific county, ${ }^{35}$ whereas others compared the WF of different crops and conversion processes. ${ }^{36,37}$ Studies of a global scope have considered most countries and a variety of crops. ${ }^{38-41}$ Yet other studies focused on second-generation biofuels based on lignocellulosic feedstock, ${ }^{36,42,43}$ or microalgae. ${ }^{44,45}$ All of these studies have shown that the production of biofuel is water-intensive and could have adverse effects on both water scarcity and water quality. The WF of biofuels is considerably larger than that of fossil fuels. For example, it requires about 187 times more water to travel one kilometer with corn bioethanol ( $66 \mathrm{~L}$ of water $/ \mathrm{km}$ traveled) compared to conventional gasoline $(0.4$ $\mathrm{L}$ of water $/ \mathrm{km}){ }^{36}$ Therefore, switching from fossil to biofuels will result in a substantial growth in water demand. ${ }^{46,47}$ Indeed, environmental impacts in the U.S. and Brazil have increased over the last few decades due to the increased production and use of biofuels.

The production of biofuel crops is highly dependent on variable water availability and climate. When the agricultural sector in the U.S. suffered from a major drought in 2012, economic losses amounted to 35 billion dollars, ${ }^{48,49}$ among the major crops, corn had the largest loss, and compared to the previous year, production and yield levels dropped by $13 \%$ and $16 \%$, respectively. ${ }^{48}$ In Brazil, the 2014 drought lead to $\sim 5$ billion dollars of economic losses and a $2.8 \%$ drop in sugar cane production. ${ }^{50,51}$ After analyzing the potential impact of climate variability on corn and bioethanol production, 
Eaves and Eaves ${ }^{52}$ concluded that replacing gasoline with bioethanol would be substituting geopolitical risk with yield risk. Such yield risks are more pronounced for crop production that solely relies on rainfall. Irrigation is generally required to meet crop water requirements and to reduce the risks of crop failure due to water stress. Stone et al. ${ }^{47}$ found that the increase of corn cultivation in the U.S. for biofuel production, as proposed in the report by Perlack et al., ${ }^{53}$ will probably have a negative impact on the nation's water resources. Overall, there is a need to preassess to what extent increased biofuel production may contribute to increasing the scarcity of water in streams, lakes, and groundwater.

Farrell et al. ${ }^{12}$ consider the energy balance as an inadequate indicator and recommend having a more complete set of policy relevant metrics to assess the environmental implications of bioethanol. While a number of researchers have studied the water, energy, and carbon footprints of bioethanol, either individually or only energy and carbon footprint together, there are, to our knowledge, no studies that combine all three footprints together. Therefore, the current study aims to simultaneously assess the water, energy, and carbon footprints of bioethanol from corn in the U.S. and from sugar cane in Brazil. For the first time, by combining the three footprints for bioethanol production from corn and sugar cane, we hope to provide an integration of relevant information for comparison and evaluation of the sustainability of the major global bioethanol producers.

\section{Materials and Methods}

\subsection{Corn-to-Bioethanol in the U.S.}

Corn (Zea mays; or maize) is a widely grown crop globally, occupying about 185 million hectares in $2014 .{ }^{54}$ China accounted for the largest share in the harvested corn area (20\%), followed by the U.S. (18\%); the U.S., however, had the largest share in global corn production (35\%), due to higher yields per hectare. ${ }^{54}$ Corn is primarily used as animal feed (55\% of global production), and for a relatively small fraction for direct human consumption (14\%). ${ }^{54}$ Only in Africa, the fraction of corn going to human consumption was larger (55\%) than for feed (32\%). In China, $69 \%$ of the corn is for animal feed and $5 \%$ for human consumption. ${ }^{54}$ In the U.S., $38 \%$ of the corn is for animal feed, $29 \%$ for bioethanol production, and a very small amount for human consumption. ${ }^{55}$ Between 2006 and 2016, the amount of corn used for bioethanol production in the U.S. had a 2.5 -fold increase. ${ }^{55}$

Bioethanol is industrially processed from corn through either dry or wet milling process. Dry milling is less capital intensive, but produces low-valued coproducts (distillers dried grain, distillers oil, and biogenic carbon dioxide)..$^{56}$ Currently, about $90 \%$ of the corn bioethanol produced in the U.S. 
is from the dry milling and the remaining $10 \%$ from wet milling. ${ }^{57}$ Besides corn grain, the milling process requires water, enzymes, ammonia, yeast, energy, and some other inputs. ${ }^{57,58}$

\subsection{Sugar Cane-to-Bioethanol in Brazil}

Sugar cane is primarily cultivated to meet the global demand for sugar, and accounts for about $80 \%$ of the global sugar production, while the remaining $20 \%$ comes mainly from sugar beets. ${ }^{59}$ Brazil and India are the largest cane sugar producers, contributing $26 \%$ and $21 \%$ of global production in 2016 , respectively. ${ }^{59}$ In 2014, harvested sugar cane area was $\sim 27$ million ha globally. Brazil accounted for $38 \%$ of total area, and India for $18 \% .^{54}$ Brazil is also the largest producer of sugar cane, accounting for $39 \%$ of the global production. ${ }^{54}$ In Brazil, market prices dictate the relative amount of sugar and bioethanol produced.

\subsection{Inputs and Outputs in Production of Ethanol}

Inputs and outputs of bioethanol production from U.S. corn and Brazilian sugar cane are shown in Table 1. Different inputs (fertilizer, chemicals, energy, farm machinery, labor, and transport) are expressed per unit of corn or sugar cane produced. The outputs (bioethanol, distillers grains, electricity) are expressed per unit of bioethanol produced. The Supporting Information (SI) provides detailed input data for the leading bioethanol producing states in the U.S. (SI Table S1) and Brazil (SI Table S2).

\subsection{Water Footprint of Bioethanol from Corn and Sugar Cane}

The water footprint of bioethanol $\left(\mathrm{WF}_{\text {eth }}\right)$ from corn or sugar cane is the sum of the direct and indirect WF along the full production chain:

$$
W F_{\text {eth }}=W F_{d, \text { farm }}+W F_{i, \text { farm }}+W F_{\text {d,proc }}
$$

where $W F_{d, f a r m}$ is the direct water use in farming (evapotranspiration from the crop field); $W_{i, f a r m}$ is the indirect water used in the production of different farm inputs, including fertilizer, fungicides, insecticides, herbicides, and machinery; and $\mathrm{WF}_{\mathrm{d} \text {,proc }}$ is direct water use in processing of the harvested crop to bioethanol. Each component is expressed in liter of water per liter of bioethanol produced ( $\mathrm{L}$ water/L bioethanol). The green and blue WF related to corn and sugar cane production were calculated based on spatially explicit data on crop water use $\left(\mathrm{m}^{3} / \mathrm{ha}\right)$ from Mekonnen and Hoekstra, ${ }_{1}^{41}$ with 2014-2016 average state level corn and sugar cane yields from USDA ${ }^{48}$ and UNICA (Brazilian Sugar cane Industry Association), ${ }^{5}$ respectively. The WFs of different farm-level inputs were collected from previous literature (Table 2). 
Table 1. Inputs and Outputs in the Production of Bioethanol from U.S. Corn and Brazilian Sugarcane

\begin{tabular}{|c|c|c|c|c|}
\hline Crop production & unit & $\begin{array}{l}\text { U.S. } \\
\text { Corn }\end{array}$ & $\begin{array}{l}\text { Brazilian } \\
\text { Sugar Cane }\end{array}$ & References \\
\hline Seed & $\mathrm{kg} / \mathrm{Mg}$ of crop & 2.45 & 31.9 & Gallagher et al.:19 AgraFNP 60 \\
\hline \multicolumn{5}{|l|}{ Fertilizer } \\
\hline nitrogen & $\mathrm{kg} / \mathrm{Mg}$ of crop & 6.94 & 1.10 & USDA; $;{ }^{48}$ Veiga et al. ${ }^{61}$ \\
\hline phosphate & $\mathrm{kg} / \mathrm{Mg}$ of crop & 5.53 & 0.29 & USDA; ${ }^{48}$ AgraFNP 60 \\
\hline potash & $\mathrm{kg} / \mathrm{Mg}$ of crop & 7.00 & 1.32 & USDA; ${ }^{48}$ Macedo et al. ${ }^{27}$ \\
\hline limestone & $\mathrm{kg} / \mathrm{Mg}$ of crop & 46 & 9.13 & Gallagher et al.:19 AgraFNP 60 \\
\hline \multicolumn{5}{|l|}{ Agrochemicals } \\
\hline fungicide & $\mathrm{g} / \mathrm{Mg}$ of crop & 5.0 & 0.01 & USDA; 48 Seabra et al. ${ }^{62}$ \\
\hline herbicide & $\mathrm{g} / \mathrm{Mg}$ of crop & 44 & 44 & USDA:48 AgraFNP 60 \\
\hline insecticide & $\mathrm{g} / \mathrm{Mg}$ of crop & 4.9 & 0.27 & USDA:48 AgraFNP 60 \\
\hline Energy use at farm ${ }^{a}$ & $\mathrm{MJ} / \mathrm{Mg}$ of $\mathrm{crop}$ & 233 & 150 & Gallagher et al. ${ }^{19}$ AgraFNP 60 \\
\hline diesel & $\%$ & 62.8 & 38.3 & \\
\hline gasoline & $\%$ & 22.4 & 12.3 & \\
\hline LPG & $\%$ & 3.96 & 18.8 & \\
\hline natural gas & $\%$ & 3.42 & 21.5 & \\
\hline electricity & $\%$ & 7.38 & 9.10 & \\
\hline \multicolumn{5}{|c|}{ Water consumption in crop production ${ }^{b}$} \\
\hline blue water & $\mathrm{m}^{3} / \mathrm{Mg}$ of crop & 29 & 4 & estimated in this study \\
\hline green water & $\mathrm{m}^{3} / \mathrm{Mg}$ of $\mathrm{crop}$ & 387 & 101 & estimated in this study \\
\hline Labor & $\mathrm{h} / \mathrm{Mg}$ of crop & 0.24 & 0.17 & Klein et al.;63 AgraFNP 60 \\
\hline $\begin{array}{l}\text { Crop transport to } \\
\text { ethanol plant }\end{array}$ & $\mathrm{km} / \mathrm{Mg}$ of crop & 29 & 19 & $\begin{array}{l}\text { Gallagher et al. }{ }^{19} \\
\text { default value from GREET }\end{array}$ \\
\hline \multicolumn{5}{|l|}{ Ethanol Production } \\
\hline ethanol yield & $\mathrm{L} / \mathrm{Mg}$ of crop & 425 & 86 & RFA; ${ }^{57}$ Macedo et al. ${ }^{27}$ \\
\hline \multicolumn{5}{|c|}{ Inputs in Ethanol Processing } \\
\hline energy use & $\mathrm{MJ} / \mathrm{L}$ of ethanol & 7.49 & 0.27 & RFA; ${ }^{57}$ Macedo et al. ${ }^{27}$ \\
\hline $\begin{array}{l}\text { blue water } \\
\text { consumption }\end{array}$ & $\mathrm{L} / \mathrm{L}$ of ethanol & 2.7 & 19.5 & RFA $^{64}{ }^{6}$ Tsiropoulos et al. ${ }^{65}$ \\
\hline \multicolumn{5}{|l|}{ Coproducts } \\
\hline DGS yield $c$ & $\begin{array}{l}\mathrm{kg}(\mathrm{DM} \text { basis }) / \mathrm{L} \\
\text { of ethanol }\end{array}$ & 0.67 & & default GREET model value \\
\hline corn distillers oil & $\mathrm{kg} / \mathrm{L}$ of ethanol & 0.03 & & RFA 57 \\
\hline biogenic $\mathrm{CO}_{2}$ & $\mathrm{~kg} / \mathrm{L}$ of ethanol & 0.71 & & RFA ${ }^{57}$ \\
\hline electricity yield & $\mathrm{MJ} / \mathrm{L}$ of ethanol & & 3.0 & Macedo et al. ${ }^{27}$ \\
\hline
\end{tabular}

a. The share of different forms of energy input for sugar cane are the default GREET values.

b. See Section 2.4 .

c. Distillers grains and solubles (DGS) yields are based on the default GREET model displacement ratio (78.1\% corn, $30.7 \%$ soybean meal, and $2.27 \%$ urea). 
Table 2. Water Footprints of the Inputs to Bioethanol Production

\begin{tabular}{|c|c|c|c|}
\hline inputs & unit & water footprint (L/unit) & references \\
\hline \multicolumn{4}{|l|}{ Fertilizer } \\
\hline nitrogen & $g$ & 1591 & Sheehan et al. ${ }^{66}$ \\
\hline phosphate & $\mathrm{g}$ & 452 & Sheehan et al. ${ }^{66}$ \\
\hline potash & $\mathrm{g}$ & 2.4 & Sheehan et al. ${ }^{66}$ \\
\hline limestone & $\mathrm{kg}$ & $\begin{array}{c}83 \\
\text { for Clean Products } \\
{ }^{67}\end{array}$ & University of Tennessee Center \\
\hline \multicolumn{4}{|l|}{ Agrochemicals ${ }^{a}$} \\
\hline herbicide & $\mathrm{kg}$ & 2.93 & Sheehan et al. 66 \\
\hline insecticide & $\mathrm{kg}$ & 2.93 & Sheehan et al. ${ }^{66}$ \\
\hline \multicolumn{4}{|c|}{ Energy use at farm } \\
\hline diesel & $\mathrm{L}$ & 2.20 & King and Webber ${ }^{36}$ \\
\hline gasoline & $\mathrm{L}$ & 2.17 & King and Webber ${ }^{36}$ \\
\hline LPG & $\mathrm{kg}$ & 2.50 & Francke and Castro 68 \\
\hline natural gas & $\mathrm{kg}$ & 0.105 & Mekonnen et al. ${ }^{69}$ \\
\hline electricity ${ }^{b}$ & kWh & $6.71(58)$ & Mekonnen et al. ${ }^{69}$ \\
\hline
\end{tabular}

a. Assumed equal to fungicide (the biocidal chemical compounds used to kill plant parasitic fungi).

b. First value is the U.S. average and the value in bracket is the Brazil average.

\subsection{Energy and Carbon Footprints of Bioethanol Production from Corn and Sugar Cane}

To estimate the energy and carbon footprints of bioethanol from U.S. corn and Brazilian sugar cane, the GREET (Greenhouse gases, Regulated Emissions, and Energy use in Transportation) model developed by Argonne National Laboratory ${ }^{11}$ was used. The energy footprint of bioethanol is the sum of the fossil energy inputs in the different steps of the production chain minus the energy footprint allocated to coproducts $\left(\mathrm{EF}_{\mathrm{cp}}\right)$ :

$$
\mathrm{EF}_{\text {eth }}=\mathrm{EF}_{\mathrm{d}, \mathrm{farm}}+\mathrm{EF}_{\mathrm{i} \text {,farm }}+\mathrm{EF}_{\mathrm{d} \text {, proc }}+\mathrm{EF}_{\mathrm{i} \text {,proc }}-\mathrm{EF}_{\mathrm{cp}}
$$

where $\mathrm{EF}_{\mathrm{d} \text {,farm }}$ and $\mathrm{EF}_{\mathrm{i}, \text { farm }}$ are the direct and indirect energy inputs in crop production, respectively, and $\mathrm{EF}_{\mathrm{d} \text {, proc }}$ and $\mathrm{EF}_{\mathrm{i}, \text { proc }}$ are the direct and indirect energy inputs in bioethanol processing. Each component is expressed in $\mathrm{MJ} / \mathrm{L}$ of bioethanol. The direct energy use in crop production refers to the direct use of diesel, natural gas, and electricity in farming, related to pumping of water, application of fertilizer and other agrochemicals, harvesting, and transport of inputs and outputs (Table 1). The indirect energy use in crop production refers to the energy used in the production of inputs such as fertilizer, agrochemicals, and machinery (tractors, combine harvesters, and sprayers). 
The energy balance of bioethanol (net energy, $\mathrm{NE}$, in $\mathrm{MJ} / \mathrm{L}$ ) was calculated as the difference between the energy in the final bioethanol $\left(\mathrm{EO}_{\mathrm{eth}}\right)$ and the energy footprint of bioethanol:

$$
\mathrm{NE}=\mathrm{EO}_{\text {eth }}-\mathrm{EF}_{\text {eth }}
$$

The energy ratio estimates how much energy (in the form of bioethanol) is produced per unit of energy input and thus defined as

$$
\text { energy ratio }=\frac{\mathrm{EO}_{\text {eth }}}{\mathrm{EF}_{\text {eth }}}
$$

\subsection{Allocation of Footprints to Coproducts}

The two most widely used methods for coproduct allocation or determining the coproduct energy credits are the displacement (or replacement or substitution) method and the allocation method based on relative prices or energy contents of the products and coproducts. ${ }^{11,18,23,70-73}$ The GREET model provides both options. For corn, the displacement method, which assumes that the coproduct displaces another product, primarily cattle feed was used. By displacing that other product, the water and energy that is required to produce the displaced product is saved. The water and energy footprints of producing the displaced product and the associated carbon footprint is allocated to the coproduct. For corn, the coproduced distillers grains and solubles (DGS) are a suitable animal feed, thus it is given a displacement credit as cattle feed, which in fact can be quite variable. ${ }^{74}$ In the GREET model, the coproduct energy and carbon credits are calculated and provided as an output at the end of the simulation. For the water footprint, the DGS credit was calculated by multiplying the volume of displaced products (Table 1, note c) by their respective WF. In the case of sugar cane, the bagasse is used to cogenerate heat and electricity, which displace the energy required for bioethanol production. Following Wang et al., ${ }^{11}$ the energy allocation method was used to determine the coproduct water and energy credits.

Input data and model parameters are subject to uncertainties that may affect the reliability of the final result. Therefore, the GREET model's Stochastic tool and range of values (defined by the 10th and 90th percentile) for the input data provided by Wang et al. ${ }^{11}$ was used to assess the uncertainty of the energy and carbon footprints for both corn and sugar cane bioethanol. Monte Carlo sampling method with 1000 runs was used for the uncertainty ranges of 10th-90th percentile for all the input data. 


\section{Results}

\subsection{Water Footprint}

There is a significant difference in the crop yield of corn and sugar cane as well as in the bioethanol yield of the two crops. While sugar cane's total wet yield (mass per unit area) in Brazil is on average about eight times larger than that of corn in the U.S., ${ }^{48,54}$ the bioethanol output per unit of crop input (L/Mg) for corn is about five times larger than that of sugar cane (Table 1). As a result, the bioethanol yield per unit of harvested area is close to 2-fold larger for sugar cane than for corn.

The calculated WF of bioethanol from corn in the U.S. and sugar cane in Brazil is shown in Table 3. About $99 \%$ of the consumptive WF of bioethanol is related to the green and blue water lost through evapotranspiration during the crop growing season. The analysis shows a clear difference in the WF of bioethanol from corn and sugar cane. The total consumptive (blue + green) WF of sugar cane bioethanol (L water/L bioethanol) in Brazil is 2.1 times larger than for corn bioethanol in the U.S. The smaller WF of corn bioethanol per unit of ethanol compared to sugar cane bioethanol is mainly due to corn's larger bioethanol yield per unit mass and the significant WF that is credited to the coproduct DGS. About $45 \%$ of the WF of corn bioethanol is credited to the DGS that displaces corn and soybean in animal feed and urea in nitrogen fertilizer production.

The WF of corn bioethanol (Table 3 ) is the weighted average of the nine major bioethanol producing states in the U.S. (Figure 1A). To understand the implication of crop growth on water resources, data by state are more

Table 3. Green and blue water footprint of corn and sugarcane bioethanol

\begin{tabular}{|c|c|c|c|c|}
\hline \multirow{3}{*}{ Inputs } & \multicolumn{4}{|c|}{ Water footprint (L/Mg of crop) } \\
\hline & \multicolumn{2}{|c|}{ Corn in the U.S. } & \multicolumn{2}{|c|}{ Sugar cane in Brazil } \\
\hline & blue & green & blue & green \\
\hline seed & 70 & 947 & 125 & 3208 \\
\hline fertilizer and agrochemicals & 14 & & 1.9 & \\
\hline energy inputs & 46 & & 34 & \\
\hline limestone & 3803 & & 762 & \\
\hline crop water footprint & 28,534 & 386,767 & 3934 & 100,801 \\
\hline \multirow[t]{2}{*}{ total agricultural stage } & 32,619 & 387,714 & 4858 & 103,909 \\
\hline & \multicolumn{4}{|c|}{ Water Footprint (L/L of Bioethanol) } \\
\hline total agricultural stage & 77 & 913 & 56 & 1204 \\
\hline bioethanol production stage & 2.7 & & 19 & \\
\hline total water footprint & 79 & 913 & 76 & 1204 \\
\hline water credit to coproduct & 21 & 430 & 10 & 155 \\
\hline water input allocated to bioethanol & 58 & 483 & 66 & 1049 \\
\hline
\end{tabular}




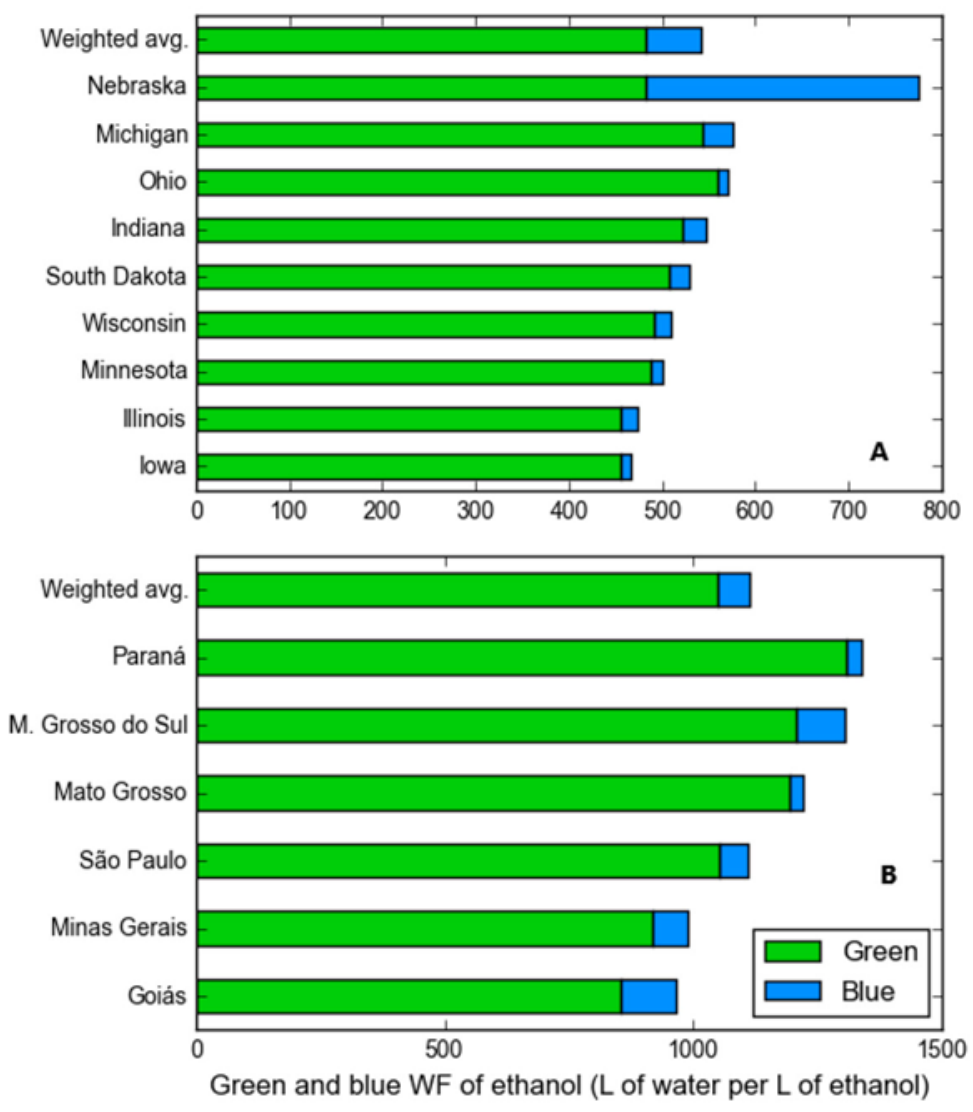

Figure 1. Green and blue WF of bioethanol from corn for the nine major bioethanol producing states in the U.S. (A) and from sugar cane for the six major states in Brazil (B).

relevant than the weighted average water footprint at national level. Due to differences in crop yield and evapotranspiration in the nine states, the WF of corn bioethanol shows spatial variation. Nebraska stands out with a large WF, both in terms of total and blue WF, due to a relatively large crop water use $\left(\mathrm{m}^{3} / \mathrm{ha}\right)$ from extensive irrigation and a relatively low crop yield. Nebraska's crop water use ( $\mathrm{m}^{3} / \mathrm{ha}$ ) was $32 \%$ larger and its corn yield in the period 2014-2016 was 5\% lower than that of lowa, where rainfed corn has the smallest consumptive WF. In Nebraska, about $65 \%$ of the corn production comes from irrigation, which is reflected in the larger blue WF of bioethanol in the state compared to others.

In Brazil, sugar cane and bioethanol production is concentrated mainly in the South-Central Region, with six states of the region contributing about 91\% to sugar cane and 92\% to bioethanol production in Brazil. São Paulo is the major producer, contributing $49 \%$ to national sugar cane bioethanol production, followed by Goiés, which contributes $15 \%$ of total sugar cane 
bioethanol production. There is a difference in the WF of sugar cane bioethanol among states (Figure 1B). Similar to the case of corn ethanol, differences in the WFs of sugar cane bioethanol among the states are due to differences in crop yield and evapotranspiration. Detailed result is presented in SI Tables S3 and S6.

Multiplying the weighted average green and blue WF of bioethanol (Table 3) by the national total bioethanol production in 2016 (58 million L bioethanol), gives a total WF of corn bioethanol production in the U.S. of 31 billion $\mathrm{L}(89 \%$ green, $11 \%$ blue,). The analysis indicates that water consumption
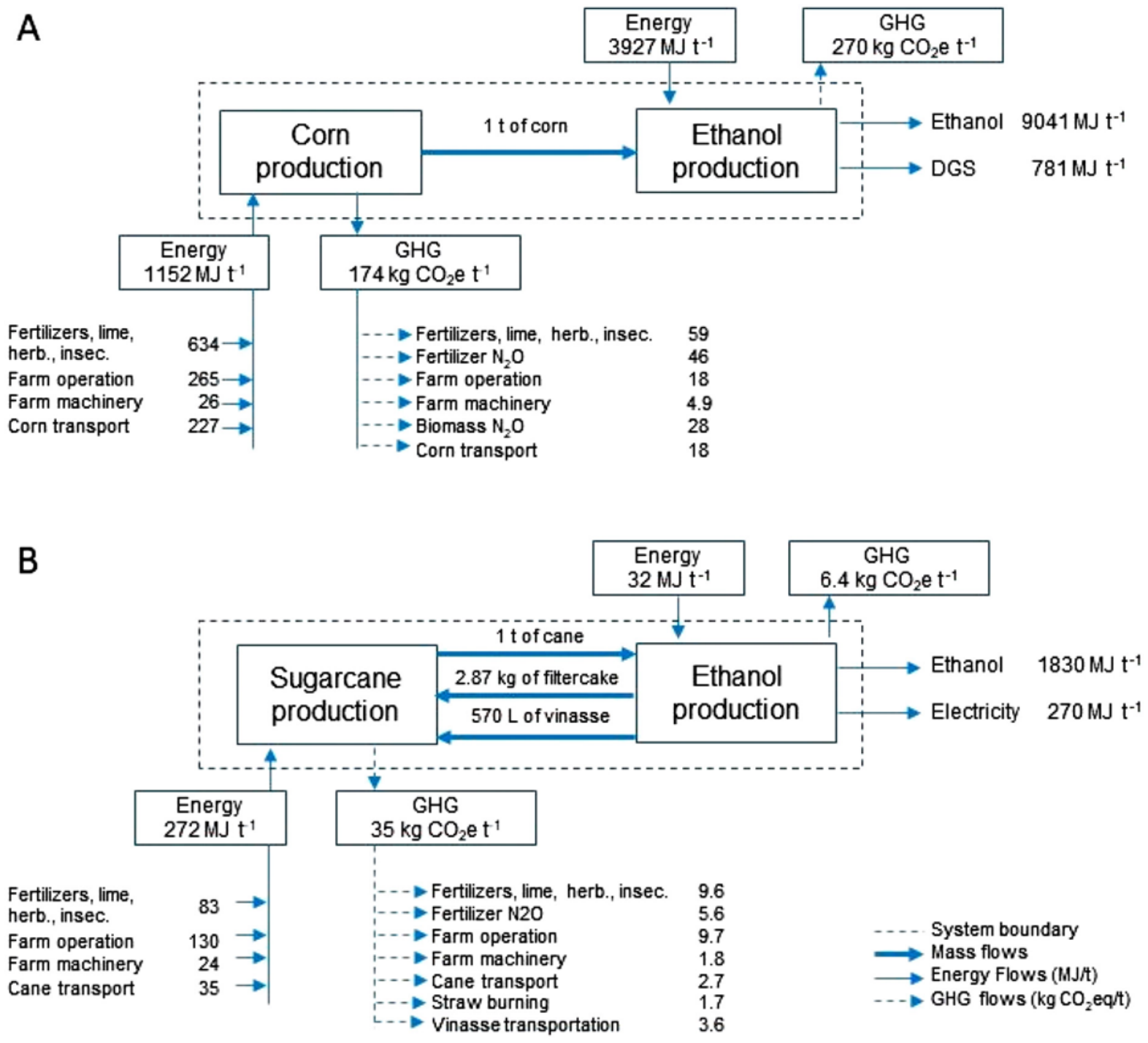

Figure 2. Energy and carbon footprint of bioethanol from corn in the U.S. (A) and sugar cane in Brazil (B). For the background data see Table 1 and SI Tables S4-S5, S7 and S8. 
in corn production is responsible for about $99 \%$ of the total WF and could have a big impact on the water systems in areas where the share of blue WF is large and where blue water consumption has been associated with the overexploitation of groundwater resources. ${ }^{75,76}$ On the other hand, $\mathrm{Ne}$ braska has instituted a system of groundwater governance that has contributed to the stability of the northern High Plains aquifer in the state. ${ }^{75}$ Since the size and type of the WF depends on local conditions, it is important that future expansion of bioethanol production takes into account the impacts on freshwater resources and to identify areas where crop growth for biofuel production may put water security at risk. Assessing the WF at higher temporal and spatial resolution would help to identify areas with low water productivity and design strategies to improve it.

\subsection{Energy Footprint}

The energy footprint of bioethanol from corn in the U.S. and sugar cane in Brazil (Figure 2) is closely related to the carbon footprint (as discussed in the next section). Bioethanol production requires substantial energy in every stage of production, from crop growth to processing the crop to bioethanol. Corn production in the U.S. requires about 4-fold more energy per unit of corn produced compared to sugar cane production in Brazil (Figure 2). The relatively low energy consumption in sugar cane production in Brazil is due to larger labor intensity and lower fertilizer input compared to U.S. corn, where farming is highly mechanized and fertilizer application rates are relatively high. The other reason for the relatively low energy intensity of sugar cane production is the high cane production (in fresh weight) per unit of harvested area. Due to the large bioethanol yield per unit of corn compared to sugar cane, the total energy used at farm level per unit of bioethanol produced is smaller for corn than for sugar cane. The fossil energy consumption per liter of bioethanol produced in a corn bioethanol plant is 25 times larger compared to sugar cane bioethanol production (Figure 3). The main reason for the big difference in the energy demand between the two bioethanol processes is that in sugar cane bioethanol production, the cogenerated energy using bagasse provides all the required energy in the bioethanol plant, whereas in corn bioethanol production external energy is used to meet the energy demand, primarily via natural gas. The inventory of the energy input shows that, for corn bioethanol, the energy input at the biorefinery accounts for $77 \%$ of the total energy input while the remaining $23 \%$ is used in corn production, harvesting, and transport. In corn farming, the largest share (69\%) of the energy input is related to energy embedded in fertilizer (primarily nitrogen) and agrochemicals input, followed by direct energy use (diesel, LPG, natural gas, electricity) in corn cultivation and harvest (29\%), and energy embedded in farm machineries (3\%). The main reason for the large energy footprint of the fertilizer in corn production is that 


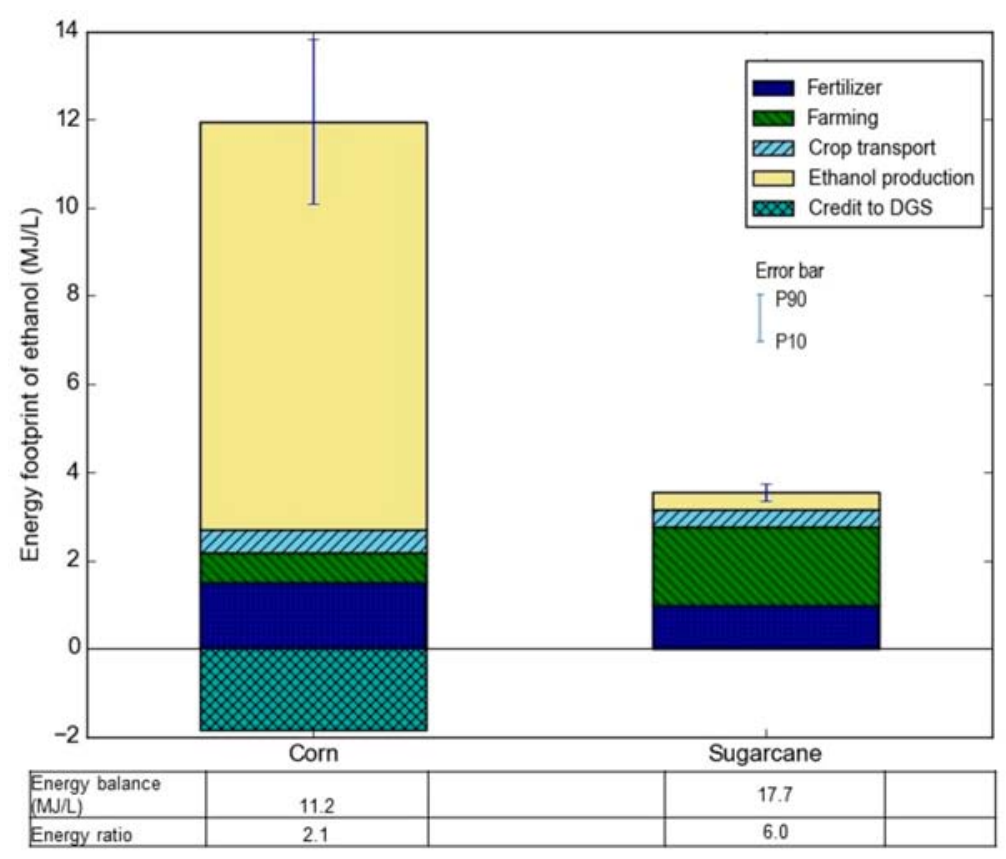

Figure 3. Energy footprint, overall energy balance, and fossil energy ratio of bioethanol from U.S. corn and Brazilian sugar cane.

the nitrogen and phosphate fertilizer application rates per unit of corn produced in the U.S. are 6 and 19 times larger, respectively, than those in sugar cane production in Brazil, where the latter has some endogenous nitrogen capture from the atmosphere via associated microorganisms. In the case of sugar cane, agricultural activities (farming, harvest, and transport) account for $78 \%$ of the total energy input. At the farm level, $55 \%$ of the total energy input in sugar cane farming is related to the direct energy use and $35 \%$ to fertilizer (mainly nitrogen fertilizer) and agrochemicals inputs (Figure 2). While the energy demand in the sugar cane biorefinery is largely met by the cogeneration system using sugar cane bagasse, in the case of corn there is no energy contribution from cogeneration, because corn residues are left on the crop field to maintain soil fertility, prevent soil erosion, and reduce evaporation from the soil surface, and partly used for animal feed and bedding; and the coproducts also provide no direct energy benefit, as they are used off-site.

Figure 3 presents the energy footprint of bioethanol from corn in the U.S. and sugar cane in Brazil. The figure shows the breakdown of the energy footprint at different stages, including fertilizer production, farming, crop transport to the ethanol plant, ethanol production, and the energy credit to the coproduct DGS for corn, and the overall energy balance and the energy 
ratio. The energy balance is the difference between the energy in the final bioethanol output and the energy input in the production of bioethanol. Both corn and sugar cane have a positive energy balance. Bioethanol from sugar cane produces roughly three times more energy output per unit of energy input compared to that of corn. The figure also shows the uncertainty ranges represented by the error bars with 10th (P10) and 90th (P90) percentile. Bioethanol from corn has wider uncertainty ranges compared to that from sugar cane, which is consistent with the result from Wang et al. ${ }^{11}$

State-level data for the nine-major corn bioethanol producing states in the U.S. show that Wisconsin and South Dakota have the most positive energy balance (net energy produced per liter of bioethanol) (Figure 4). Nebraska and Ohio have the lowest net energy per unit of bioethanol produced. Ohio also has the lowest net energy yield per unit of area owing to its low corn yield in 2014-2016. The relatively low net energy per volume of bioethanol produced in Nebraska is mainly due to the relatively large diesel and electricity consumption per unit of corn produced. About two-thirds of the corn in Nebraska is produced in irrigated fields. The bulk of the irrigation water comes from groundwater, thus requiring large amounts of energy for pumping the water. lowa, which accounts for $19 \%$ of the corn and $26 \%$
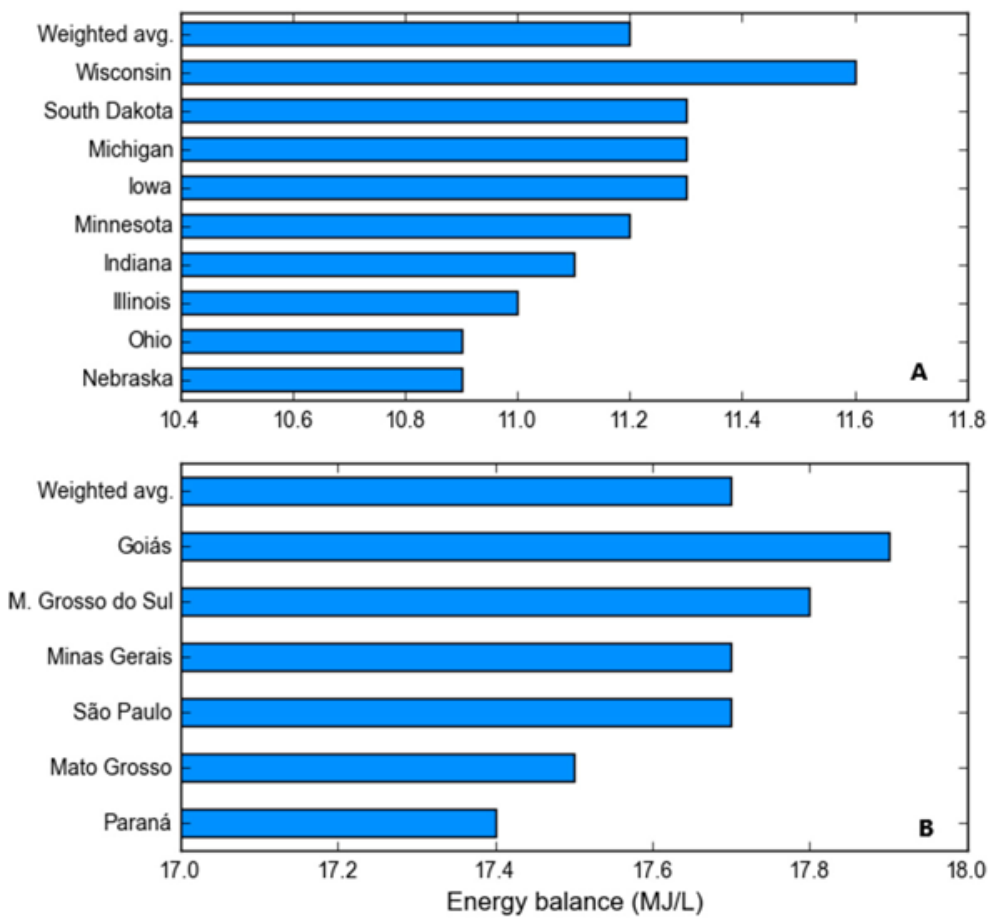

Figure 4. Energy balance per unit bioethanol produced in the nine major bioethanol producing states in the U.S. (A) and six-major bioethanol producing states in Brazil (B). 
of national bioethanol production in $2016,2,48$ has a relatively large positive energy balance and large energy output per unit of energy input, due to rainfed crop production and high crop yields, which confirms previous findings of Liska et al. ${ }^{21}$ lowa has some of the highest corn yields in the U.S., and the lowest energy input per unit of corn produced compared to the other states. Farmlands in lowa heavily rely on rainfall, requiring less energy for irrigation, which contributes to the low energy intensity of corn in the state.

In Brazil, Goiás has the largest and Paraná the smallest net energy per unit of bioethanol produced. The relatively low net energy per unit of bioethanol in Paranáis due to the relatively low sugar cane yield and relatively large nitrogen fertilizer input per unit of sugar cane produced. Figure 4 data were derived from SI Table S4 and Table S7.

\subsection{Carbon Footprint}

Bioethanol production is mainly driven by its potential contribution to reduce GHG emissions by replacing fossil fuels, and to maintain higher crop prices for farmers. The computed life cycle GHG emissions from the production of bioethanol from corn in the U.S. and sugar cane in Brazil are shown in Figure 5. The GHG emissions estimated here include emissions related to the indirect land use change (ILUC), although the estimates are very conservative. In particular the error bars between the P10 and P90 are conservative because they did not capture the full extent of the uncertainty related to land use changes (LUC). According to USEPA, ${ }^{77}$ ILUC can contribute as much as 26.5 and $3.8 \mathrm{~g} \mathrm{CO}_{2} \mathrm{e} \mathrm{MJ}^{-1}$ to the total GHG emissions from corn (40\%)

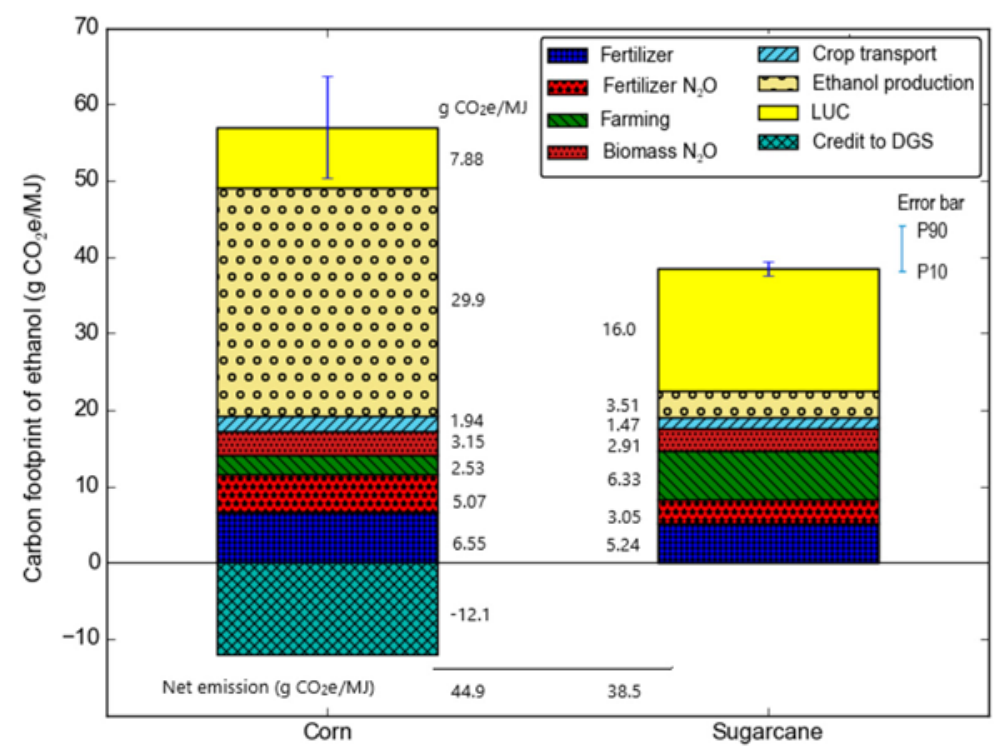

Figure 5. Carbon footprint of bioethanol from corn in the U.S. and sugar cane in Brazil. 
and sugar cane (14\%) bioethanol, respectively, although the latter may be conservative. ${ }^{23,78}$ Plevin et al. ${ }^{78}$ showed that the average GHG emission from ILUC for both U.S. corn and Brazilian sugar cane bioethanol is $25 \mathrm{~g} \mathrm{CO}_{2} \mathrm{e}$ $\mathrm{MJ}^{-1}$ and can vary within $\pm 20 \mathrm{~g} \mathrm{CO}_{2} \mathrm{e} \mathrm{MJ}^{-1}$ around the mean. Bioethanol from sugar cane outperforms that of corn in terms of life cycle GHG emissions. The net GHG emissions from sugar cane bioethanol are $57 \%$ of corn bioethanol when LUC is excluded and $86 \%$ when LUC is included. In corn bioethanol, the bioethanol production phase accounts for $52 \%$ of life cycle GHG emissions. In sugar cane bioethanol, $49 \%$ of life cycle GHGs emission is from sugar cane production and transport. The GHG emissions from production of fertilizer and agrochemicals, plus the $\mathrm{N}_{2} \mathrm{O}$ conversion from nitrogen fertilizer account for $22 \%$ and $20 \%$ of the life cycle GHG emissions from sugar cane and corn bioethanol, respectively. These relatively large shares of life cycle GHG emissions from fertilizer, emphasize the need to properly manage nitrogen fertilizer use in crop production.

The coproducts from bioethanol production replace a portion of conventional fossil fuels, thus significantly reducing GHG emissions. In corn bioethanol, DGS replace animal feed and about $21 \%$ of the life cycle GHG emissions per unit of bioethanol produced. In sugar cane bioethanol, the biorefinery uses cogenerated heat and electricity from bagasse, thus reducing the GHG emission considerably.

\section{Discussion}

The water, energy, and carbon footprints of bioethanol from corn and sugar cane was assessed. Although bioethanol from both corn and sugar cane has a positive energy balance, sugar cane bioethanol has a 1.6 times larger net energy output per liter compared to that of corn. Furthermore, sugar cane has a 2.9 times larger energy output per unit of energy input compared to corn (Figure 3). Sugar cane also has a smaller GHG emission compared to corn. Overall, the metrics favor sugar cane as the best option, although its cultivation is limited to tropical and semitropical settings, thus making it unsuitable for the environmental conditions in the U.S. (except Florida and southern U.S.); but a serious downside risk for sugar cane is its probable negative impacts on tropical biodiversity. ${ }^{79}$ The U.S. climatic conditions are more suitable for corn. As shown earlier, there is a clear difference in the water and energy intensity of corn and sugar cane bioethanol among the different states. In case of further industry expansion, supporting bioethanol production areas with smaller water and energy footprints while also working to reduce the water and energy footprints in those areas where the footprints are large, could enhance the overall environmental performance of bioethanol. 
The results show that the agricultural stage contributes a major share in bioethanol's total water footprint (nearly $100 \%$ for both corn and sugar cane), energy footprint (18\% for corn and $78 \%$ for sugar cane), and carbon footprint ( $30 \%$ for corn and $46 \%$ for sugar cane), suggesting that significant improvement in the environmental performance of bioethanol from corn and sugar cane can be achieved if policies are targeted at reducing the environmental footprints in the agricultural stage. In particular, the major contribution of nitrogen fertilizer to the total energy and carbon footprints emphasizes the need for reducing nitrogen fertilizer use in crop production. Improved agricultural practices such as conservation tillage, use of cover crops, recycling crop residues in the field, and intercropping with leguminous ( $\mathrm{N}$ fixing) crops will reduce both the energy and carbon footprints of crop production. . $^{1,80-84}$

As this and other recent works ${ }^{11,12,21}$ show, corn-ethanol has a positive energy balance and lower GHG emission compared to gasoline. However, the growing production of biofuel crops has increased pressure on limited water resources. Irrigated corn in particular increases the competition for water with other irrigated crops and economic sectors, which is highly relevant in states where irrigated corn contributes to the depletion of the central and southern High Plains aquifer. ${ }^{75,76}$ Therefore, the potential impact of biofuel mandates on water resources needs to be evaluated to minimize the degree to which biofuels will contribute to water depletion and pollution. Bioethanol will also have to be evaluated against alternative renewable forms of energy, like solar and wind energy, which have a much smaller WF than biofuels ${ }^{69}$ and a more favorable energy balance as well, ${ }^{85}$ and which can be used in electrified transport or used to produce hydrogen-fuel.

By estimating footprints at state level, the current study shows differences in the regional water and energy footprints of bioethanol from corn and sugar cane. This demonstrates the importance of and need for higherresolution spatial analysis of the different footprints in order to get a clearer picture of the sustainability metrics of bioethanol production for increased regional optimization. Identifying areas that are at risk of water scarcity and groundwater depletion require high spatial and temporal assessment of the WF of crop production. In addition, even when corn for bioethanol is produced in parts of the U.S. with higher rainfall, there will remain the issue that the land and water resources used could alternatively be used for food production. The current study has focused on consumptive water use while nutrient loads from agriculture and biorefineries could have significant impacts on water quality as well. Thus, future researches need to assess the water quality implications of biofuels production.

The results from the current study are compared with earlier studies (Table 4). The data for the current study were derived from Tables 3, and Figures 3 and 5. The estimated energy balances and GHG emissions in the current 
Table 4. Summary and comparison of the energy balance, ghg emissions, and blue water footprint from the current study and earlier studies

\begin{tabular}{|c|c|c|c|c|c|c|}
\hline & \multicolumn{2}{|c|}{$\begin{array}{l}\text { Energy balance } \\
(M J / L)\end{array}$} & \multicolumn{2}{|c|}{$\begin{array}{l}\text { GHG emission } \\
\left(\mathrm{CO}_{2} \mathrm{e} / \mathrm{MJ}\right)\end{array}$} & \multicolumn{2}{|c|}{$\begin{array}{l}\text { blue water } \\
\text { footprint (L/L) }\end{array}$} \\
\hline & corn & $\begin{array}{l}\text { sugar } \\
\text { cane }\end{array}$ & corn & $\begin{array}{l}\text { sugar } \\
\text { cane }\end{array}$ & corn & $\begin{array}{l}\text { sugar } \\
\text { cane }\end{array}$ \\
\hline Macedo et al. ${ }^{27}$ & & 22.6 & & 10.0 & & \\
\hline Liska et al. ${ }^{21}$ & & & 42.0 & & & \\
\hline Seabra et al..$^{62}$ & & & & 18.7 & & \\
\hline Wang et al. $11 a$ & 10.1 & 16.4 & 49.0 & 17.0 & & \\
\hline Gallagher et al..$^{19}$ & 11.4 & & & & & \\
\hline Manochio et al. ${ }^{58}$ & 4.71 & 21.7 & & 12.4 & & \\
\hline Chiu et al. $33 b$ & & & & & 109 & \\
\hline Liu et al. $.86 b$ & & & & & 95 & \\
\hline Mekonnen and Hoekstra $41 b$ & & & & & 91 & 127 \\
\hline current study & 11.2 & 17.7 & 39.2 & 22.5 & 58 & 66 \\
\hline
\end{tabular}

a. Total emissions minus emissions from land use change, bioethanol transport, distribution, and combustion.

b. The average of the nine states in the U.S. for corn and six states in Brazil for sugar cane shown in Figure 1.

study are very close to the values found in previous literature. The energy balance of corn in the current study $(11.2 \mathrm{MJ} / \mathrm{L})$ is very close to the values from Wang et al. ${ }^{11}$ and Gallagher et al. ${ }^{19}$ This is to be expected as these studies used the same method (GREET model) and similar input data. For sugar cane, the value from the current study is within the range of values found in previous literature. For GHG emissions, the value for corn bioethanol is on the low side compared to the values found previously. ${ }^{11,21}$ The difference lies mainly in the estimated $\mathrm{N}_{2} \mathrm{O}$ emissions related to fertilizer and biomass remaining on the field. The water footprint estimates in the current study are smaller than those found in the earlier studies. The values presented by Chiu et al. ${ }^{33}$ and Liu et al. ${ }^{86}$ refer to applied irrigation depth and not the actual blue water footprint, which explains their high values. In addition, both studies did not account for coproduct credits, thus overestimating the blue WF of the bioethanol. The study by Mekonnen and Hoekstra ${ }^{41}$ also did not account for coproduct credit, thus allocating the full WF to the bioethanol. The wide variation of the energy balance, GHG emissions, and blue water footprint of corn bioethanol from the different studies illustrates their different assumption and system boundaries. ${ }^{18}$

The environmental footprints of both corn and sugar cane bioethanol are subject to significant uncertainties. The error bars between P10 and P90 are larger for corn, showing corn bioethanol values have larger uncertainty than those for sugar cane. This is consistent with the finding of Wang et al. ${ }^{11}$ Since the uncertainty ranges do not include the uncertainty in the ILUC 
emissions, the estimated uncertainties are very conservative. ${ }^{23,78}$ The uncertainty in the water footprint of crops can vary within $\pm 30 \% 87$ largely due to the uncertainty in precipitation and reference evapotranspiration. Different assumptions related to parameters and input data used will determine the reliability of the result of the environmental footprints of bioethanol from both corn and sugar cane. In particular, coproduct allocation, nitrogen fertilizer $\mathrm{N}_{2} \mathrm{O}$ conversion rates, and ILUC will have relatively large effect on the final result. ${ }^{11,21}$ Therefore, these parameters should be the focal point of future research in order to reduce the uncertainty.

A number of strategies exist to reduce the environmental footprint of bioethanol. Most of the efforts to date focus on increases in the productivity of crop production, biomass-to-ethanol conversion efficiency, and the energy efficiency of the different inputs. Efficient application and management of nitrogen fertilizers could significantly reduce GHG emissions per unit of energy produced, and reduce water pollution simultaneously. ${ }^{88,89}$ Growing concerns around bioethanol have also raised attention to the potential use of second-generation biofuels, which are believed to provide significant GHG emissions reductions, and potentially reduce the competition with food crops for the available land and water. However, the high cost of secondgeneration biofuel biorefineries could be a barrier for its expansion. ${ }^{90}$ In addition, expansion of second-generation biofuels may still put extra pressure on the freshwater resources, especially in water-stressed countries. The use of crop residues could help to reduce the total WF, but may also increase GHG emissions per unit energy. ${ }^{91}$

Biofuel targets are mainly developed as a means to reduce GHG emissions and secure domestic energy supply but rarely account for the unintended impacts on the limited freshwater resources. Expanded production of biofuel to meet national goals could adversely impact regional and local water resources, both quantitatively and qualitatively. Various studies have shown that increasing biofuel volumes in the transport sector will inevitably result in larger land and water footprints. ${ }^{35,38,46}$ The question is thus not only what feedstock can best be used in biofuel production, but also to which extent policies promoting biofuels need to take into account the social, economic, and environmental tradeoffs. From a perspective of using our limited water resources sustainably, it is vitally important to take into consideration the water implications when developing biofuel policies.

Acknowledgments - We thank the U.S. Fulbright Commission for supporting the Fulbright Chair in Agricultural Sciences at University of Nebraska-Lincoln (T.L.R.) in 2017.

The authors declare no competing financial interest. 


\section{References}

1) Peters, J.; Thielmann, S. Promoting biofuels: Implications for developing countries. Energy Policy 2008, 36 (4), 1538-1544.

2) RFA. Ethanol Industry Statistics; Renewable Fuels Association (RFA): Washington, DC, 2017.

3) USEPA. Regulation of Fuels and Fuel Additives: Changes to Renewable Fuel Standard Program; Final Rule in 40 CFR Part 80. Fed. Regist., 2010, 75 (58), 14669-15320.

4) MAPA. Resolution No. 1 (in Portugese); Inter Ministry council of Sugar and Ethanol, Ministry of Agriculture, Livestock and Supply (MAPA), 2015; Vol. 1.

5) UNICA (Brazilian Sugarcane Industry Association) UNICA Data Center. http://www.unicadata.com.br/historico-de-producao-emoagem. php?idMn=32\&tipoHistorico=4 (accessed 20 September 2018).

6) Searchinger, T.; Edwards, R.; Mulligan, D.; Heimlich, R.; Plevin, R. Do biofuel policies seek to cut emissions by cutting food? Science 2015, 347 (6229), $1420-1422$.

7) National Research Council. Renewable Fuel Standard: Potential Economic and Environmental Effects of U.S. Biofuel Policy, The National Academies Press: Washington, DC, 2011; p 416.

8) Pimentel, D.; Pimentel, M. Sustainability of meat-based and plant-based diets and the environment. Am. J. Clin. Nutr. 2003, 78 (3), 660S-663S.

9) Pimentel, D.; Patzek, T. W. Ethanol Production Using Corn, Switchgrass, and Wood; Biodiesel Production Using Soybean and Sunflower. Nat. Resour. Res. 2005, 14 (1), 65-76.

10) Hammerschlag, R. Ethanol's Energy Return on Investment: A Survey of the Literature 1990-Present. Environ. Sci. Technol. 2006, 40 (6), 1744-1750.

11) Wang, M.; Han, J.; Dunn, J. B.; Cai, H.; Elgowainy, A. Well-to-wheels energy use and greenhouse gas emissions of ethanol from corn, sugarcane and cellulosic biomass for US use. Environ. Res. Lett. 2012, 7 (4), No. 045905.

12) Farrell, A. E.; Plevin, R. J.; Turner, B. T.; Jones, A. D.; Hare, M.; Kammen, D. M. Ethanol Can Contribute to Energy and Environmental Goals. Science 2006, 311 (5760), 506-508.

13) Keeney, D. R.; DeLuca, T. H. Biomass as an energy source for the midwestern U.S. Am. J. Alternative Agric. 1992, 7 (3), 137-144.

14) Marland, G.; Turhollow, A. F. $\mathrm{CO}_{2}$ emissions from the production and combustion of fuel ethanol from corn. Energy 1991, 16 (11), 1307-1316.

15) Pimentel, D. Ethanol fuels: Energy security, economics, and the environment. J. Agr. Environ. Ethics 1991, 4 (1), 1-13.

16) Pimentel, D. The Limitations of Biomass Energy, 3rd ed.; Academic Press: Cambridge, MA, 2001; Vol. 2, p 159-171.

17) Pimentel, D. Ethanol Fuels: Energy Balance, Economics, and Environmental Impacts Are Negative. Nat. Resour. Res. 2003, 12 (2), 127-134. 
18) Liska, A. J.; Cassman, K. G. Towards Standardization of Life-Cycle Metrics for Biofuels: Greenhouse Gas Emissions Mitigation and Net Energy Yield. J. Biobased Mater. Bioenergy 2008, 2 (3), 187-203.

19) Gallagher, P. W.; Yee, W. C.; Baumes, H. S. 2015 Energy Balance for the Corn-Ethanol Industry; U.S. Department of Agriculture, Office of the Chief Economist, Office of Energy Policy and New Uses: Washington, DC, 2016.

20) Shapouri, H.; Gallagher, P. W.; Nefstead, W.; Schwartz, R.; Noe, S.; Conway, R. 2008 Energy Balance for the Corn-Ethanol Industry, U.S. Department of Agriculture, Office of the Chief Economist, Office of Energy Policy and New Uses: Washington, DC, 2010.

21) Liska, A. J.; Yang, H. S.; Bremer, V. R.; Klopfenstein, T. J.; Walters, D. T.; Erickson, G. E.; Cassman, K. G. Improvements in Life Cycle Energy Efficiency and Greenhouse Gas Emissions of Corn-Ethanol. J. Ind. Ecol. 2009, 13 (1), 58-74.

22) Wang, M.; Wu, M.; Huo, H. Life-cycle energy and greenhouse gas emission impacts of different corn ethanol plant types. Environ. Res. Lett. 2007, 2 (2), No. 024001.

23) Liska, A. J., Eight Principles of Uncertainty for Life Cycle Assessment of Biofuel Systems. In Sustainable Biofuels: An Ecological Assessment of Future Energy; Bhardwaj, A. K.; Zenone, T.; Chen, J. K., Eds.; Walter De Gruyter: Berlin, 2015.

24) Liska, A. J.; Perrin, R. K. Securing Foreign Oil: A Case for Including Military Operations in the Climate Change Impact of Fuels. Environment 2010, 52 (4), 9-22.

25) Chum, H. L.; Zhang, Y.; Hill, J.; Tiffany, D. G.; Morey, R. V.; Goss Eng, A.; Haq, Z. Understanding the evolution of environmental and energy performance of the US corn ethanol industry: evaluation of selected metrics. Biofuels, Bioprod. Biorefin. 2014, 8 (2), 224-240.

26) Chum, H. L.; Warner, E.; Seabra, J. E. A.; Macedo, I. C. A comparison of commercial ethanol production systems from Brazilian sugarcane and US corn. Biofuels, Bioprod. Biorefin. 2014, 8 (2), 205-223.

27) Macedo, I. C.; Seabra, J. E. A.; Silva, J. E. A. R. Green house gases emissions in the production and use of ethanol from sugarcane in Brazil: The 2005/2006 averages and a prediction for 2020. Biomass Bioenergy 2008, 32 (7), 582-595.

28) Searchinger, T.; Heimlich, R.; Houghton, R. A.; Dong, F.; Elobeid, A.; Fabiosa, J.; Tokgoz, S.; Hayes, D.; Yu, T.-H. Use of U.S. Croplands for Biofuels Increases Greenhouse Gases Through Emissions from Land-Use Change. Science 2008, 319 (5867), 1238-1240.

29) Fargione, J.; Hill, J.; Tilman, D.; Polasky, S.; Hawthorne, P. Land Clearing and the Biofuel Carbon Debt. Science 2008, 319 (5867), 1235-1238.

30) FAO. AQUASTAT Database; Food and Agriculture Organization of the United Nations (FAO): Rome, Italy, 2016.

31) Hoekstra, A. Y; Mekonnen, M. M. The water footprint of humanity. Proc. Natl. Acad. Sci. U. S. A. 2012, 109 (9), 3232-3237.

32) Hoekstra, A. Y.; Chapagain, A. K.; Aldaya, M. M.; Mekonnen, M. M. The Water Footprint Assessment Manual: Setting the Global Standard; Earthscan: London, UK, 2011. 
33) Chiu, Y.-W.; Walseth, B.; Suh, S. Water Embodied in Bioethanol in the United States. Environ. Sci. Technol. 2009, 43 (8), 2688-2692.

34) Hernandes, T. A. D.; Bufon, V. B.; Seabra, J. E. A. Water footprint of biofuels in Brazil: assessing regional differences. Biofuels, Bioprod. Biorefin. 2014, 8 (2), $241-252$.

35) Dominguez-Faus, R.; Powers, S. E.; Burken, J. G.; Alvarez, P. J. The Water Footprint of Biofuels: A Drink or Drive Issue? Environ. Sci. Technol. 2009, 43 (9), 3005-3010.

36) King, C. W.; Webber, M. E. Water Intensity of Transportation. Environ. Sci. Technol. 2008, 42 (21), 7866-7872.

37) Singh, S.; Kumar, A. Development of water requirement factors for biomass conversion pathway. Bioresour. Technol. 2011, 102 (2), 1316-1328.

38) Gerbens-Leenes, P. W.; Lienden, A. R. v.; Hoekstra, A. Y.; van der Meer, T. H. Biofuel scenarios in a water perspective: The global blue and green water footprint of road transport in 2030. Global Environ. Change 2012, 22 (3), 764-775.

39) Gerbens-Leenes, W.; Hoekstra, A. Y.; van der Meer, T. H. The water footprint of bioenergy. Proc. Natl. Acad. Sci. U. S. A. 2009, 106 (25), 10219-10223.

40) Gerbens-Leenes, P. W.; Hoekstra, A. Y.; van der Meer, T. The water footprint of energy from biomass: A quantitative assessment and consequences of an increasing share of bio-energy in energy supply. Ecolog. Econ. 2009, 68 (4), 1052-1060.

41) Mekonnen, M. M.; Hoekstra, A. Y. The green, blue and grey water footprint of crops and derived crop products. Hydrol. Earth Syst. Sci. 2011, 15 (5), 1577-1600.

42) Mathioudakis, V.; Gerbens-Leenes, P. W.; Van der Meer, T. H.; Hoekstra, A. $Y$. The water footprint of second-generation bioenergy: A comparison of biomass feedstocks and conversion techniques. J. Cleaner Prod. 2017, 148, $571-582$.

43) Wong, A.; Zhang, H.; Kumar, A. Life cycle water footprint of hydrogenationderived renewable diesel production from lignocellulosic biomass. Water Res. 2016, 102 (Supplement C), 330-345.

44) Yang, J.; Xu, M.; Zhang, X.; Hu, Q.; Sommerfeld, M.; Chen, Y. Life-cycle analysis on biodiesel production from microalgae: Water footprint and nutrients balance. Bioresour. Technol. 2011, 102 (1), 159-165.

45) Gerbens-Leenes, P. W.; Xu, L.; de Vries, G. J.; Hoekstra, A. Y. The blue water footprint and land use of biofuels from algae. Water Resour. Res. 2014, 50 (11), 8549-8563.

46) Mekonnen, M. M.; Gerbens-Leenes, P. W.; Hoekstra, A. Y. Future electricity: The challenge of reducing both carbon and water footprint. Sci. Total Environ. 2016, 569-570, 1282-1288.

47) Stone, K. C.; Hunt, P. G.; Cantrell, K. B.; Ro, K. S. The potential impacts of biomass feedstock production on water resource availability. Bioresour. Technol. 2010, 101 (6), 2014-2025. 
48) USDA. Agricultural Statistics Data Base (Quick Stats); U.S. Department of Agriculture, National Agricultural Statistics Service (USDA-NASS): Washington, DC, 2017.

49) Grigg, N. S. The 2011-2012 drought in the United States: new lessons from a record event. International Journal of Water Resources Development 2014, 30 (2), 183-199.

50) UNICA (Brazilian Sugarcane Industry Association) Drought, Lower Yields Reduce Cane Supply For 2014/2015 Sugarcane Season In South-Central Brazil. http://www.unica.com.br/unica/ (accessed 26 September, 2018).

51) Guha-Sapir, D.; Hoyois, P.; Wallemacq, P.; Below, R. Annual Disaster Statistical Review 2016: The Numbers and Trends; Centre for Research on the Epidemiology of Disasters (CRED): Brussels, 2016.

52) Eaves, J.; Eaves, S. Renewable corn-ethanol and energy security. Energy Policy 2007, 35 (11), 5958-5963.

53) Perlack, R. D.; Wright, L. L.; Turhollow, A. F.; Graham, R. L.; Stokes, B. J.; Erbach, D. C. Biomass As Feedstock for a Bioenergy and Bioproducts Industry: The Technical Feasibility of a Billion-Ton Annual Supply, DOE/GO-1020052135ORNL/TM-2005/66; Oak Ridge National Laboratory, U.S. Department of Energy: Oak Ridge, 2005.

54) FAO, FAOSTAT online database. FAO: Rome, 2017.

55) National Corn Growers Association. World of Corn; National Corn Growers Association Washington DC, 2017.

56) Rajagopalan, S.; Ponnampalam, E.; McCalla, D.; Stowers, M. Enhancing profitability of dry mill ethanol plants. Appl. Biochem. Biotechnol. 2005, 120 (1), 37-50.

57) RFA Building Partnerships, Growing Markets: 2017 Ethanol Industry outlook; Renewable Fuels Association (RFA): Washington, DC, 2017.

58) Manochio, C.; Andrade, B. R.; Rodriguez, R. P.; Moraes, B. S. Ethanol from biomass: A comparative overview. Renewable Sustainable Energy Rev. 2017, 80 (SupplementC), 743-755.

59) USDA-FAS. Production Supply \& Distribution (PS\&D) website; U.S. Department of Agriculture, Foreign Agricultural Service Washington, DC, 2017. https:// apps.fas.usda.gov/psdonline/app/index.html\#/app/advQuery

60) AgraFNP. Agrianual Yearbook of Brazilian Agriculture (in Portuguese); AgraFNP Consultoria e Comércio: São Paulo, Brazil, 2015.

61) Veiga, J. P. S.; Romanelli, T. L.; Gimenez, L. M.; Busato, P.; Milan, M. Energy embodiment in Brazilian agriculture: an overview of 23 crops. Sci. Agric. 2015, $72,471-477$.

62) Seabra, J. E. A.; Macedo, I. C.; Chum, H. L.; Faroni, C. E.; Sarto, C. A. Life cycle assessment of Brazilian sugarcane products: GHG emissions and energy use. Biofuels, Bioprod. Biorefin. 2011, 5 (5), 519-532.

63) Klein, R. N.; Wilson, R. K.; Groskopf, J. T.; Jansen, J. A. 2017 Nebraska Crop Budgets; Nebraska Extension, University of Nebraska: Lincoln, NE, 2017.

64) RFA. Fueling a High Octane Future: 2016 Ethanol Industry Outlook; Renewable Fuels Association (RFA): Washington, DC, 2016. 
65) Tsiropoulos, I.; Faaij, A. P. C.; Seabra, J. E. A.; Lundquist, L.; Schenker, U.; Briois, J.-F.; Patel, M. K. Life cycle assessment of sugarcane ethanol production in India in comparison to Brazil. Int. J. Life Cycle Assess. 2014, 19 (5), 1049-1067.

66) Sheehan, J.; Camobreco, V.; Duffield, J.; Graboski, M.; Shapouri, H. Life Cycle Inventory of Biodiesel and Petroleum Diesel for Use in an Urban Bus; National Renewable Energy Laboratory; U.S. Department of Energy: Golden, CO, 1998.

67) University of Tennessee Center for Clean Products. Limestone Quarrying and Processing: A Life-Cycle Inventory, Natural Stone Council; The Natural Stone Council, 2008.

68) Francke, I. C. M.; Castro, J. F. W. Carbon and water footprint analysis of a soap bar produced in Brazil by Natura Cosmetics. Water Resources and Industry 2013, 1-2 (0), 37-48.

69) Mekonnen, M. M.; Gerbens-Leenes, P. W.; Hoekstra, A. The consumptive water footprint of electricity and heat: A global assessment. Environmental Science: Water Research \& Technology 2015, 1, 285-297.

70) Wang, M.; Huo, H.; Arora, S. Methods of dealing with coproducts of biofuels in life-cycle analysis and consequent results within the U.S. context. Energy Policy 2011, 39 (10), 5726-5736.

71) Carneiro, M. L. N. M.; Pradelle, F.; Braga, S. L.; Gomes, M. S. P.; Martins, A. R. F. A.; Turkovics, F.; Pradelle, R. N. C. Potential of biofuels from algae: Comparison with fossil fuels, ethanol and biodiesel in Europe and Brazil through life cycle assessment (LCA). Renewable Sustainable Energy Rev. 2017, 73, 632-653.

72) Cherubini, F.; Strømman, A. H.; Ulgiati, S. Influence of allocation methods on the environmental performance of biorefinery products $\square$ A case study. Resources, Conservation and Recycling 2011, 55 (11), 1070-1077.

73) Börjesson, P.; Tufvesson, L. M. Agricultural crop-based biofuels - resource efficiency and environmental performance including direct land use changes. J. Cleaner Prod. 2011, 19 (2), 108-120.

74) Bremer, V. R.; Liska, A. J.; Klopfenstein, T. J.; Erickson, G. E.; Yang, H. S.; Walters, D. T.; Cassman, K. G. Emissions Savings in the Corn-Ethanol Life Cycle from Feeding Coproducts to Livestock. J. Environ. Qual. 2010, 39 (2), 472-482.

75) Scanlon, B. R.; Faunt, C. C.; Longuevergne, L.; Reedy, R. C.; Alley, W. M.; McGuire, V. L.; McMahon, P. B. Groundwater depletion and sustainability of irrigation in the US High Plains and Central Valley. Proc. Natl. Acad. Sci. U. S. A. 2012, 109 (24), 9320-9325.

76) Konikow, L. F. Groundwater Depletion in the United States 1900- 2008): Scientific Investigations Report 2013-5079; 2328-0328; U.S. Geological Survey: Reston,VA, 2013; p 63.

77) USEPA. Renewable Fuel Standard Program (RFS2) Regulatory Impact Analysis; United States Environmental Protection Agency: Washington DC, 2010.

78) Plevin, R. J.; Beckman, J.; Golub, A. A.; Witcover, J.; O'Hare, M. Carbon Accounting and Economic Model Uncertainty of Emissions from BiofuelsInduced Land Use Change. Environ. Sci. Technol. 2015, 49 (5), 2656-2664.

79) Goldemberg, J.; Coelho, S. T.; Guardabassi, P. The sustainability of ethanol production from sugarcane. Energy Policy 2008, 36 (6), 2086-2097. 
80) Camargo, G. G. T.; Ryan, M. R.; Richard, T. L. Energy Use and Greenhouse Gas Emissions from Crop Production Using the Farm Energy Analysis Tool. BioScience 2013, 63 (4), 263-273.

81) Kim, S.; Dale, B. E. Life cycle assessment of various cropping systems utilized for producing biofuels: Bioethanol and biodiesel. Biomass Bioenergy 2005, 29 (6), 426-439.

82) Snyder, C. S.; Bruulsema, T. W.; Jensen, T. L.; Fixen, P. E. Review of greenhouse gas emissions from crop production systems and fertilizer management effects. Agric., Ecosyst. Environ. 2009, 133 (3), 247-266.

83) Tilman, D.; Balzer, C.; Hill, J.; Befort, B. L. Global food demand and the sustainable intensification of agriculture. Proc. Natl. Acad. Sci. U. S. A. 2011, 108 (50), 20260-20264.

84) Gebbers, R.; Adamchuk, V. I. Precision Agriculture and Food Security. Science 2010, 327 (5967), 828-831.

85) Raugei, M.; Sgouridis, S.; Murphy, D.; Fthenakis, V.; Frischknecht, R.; Breyer, C.; Bardi, U.; Barnhart, C.; Buckley, A.; Carbajales-Dale, M.; Csala, D.; de WildScholten, M.; Heath, G.; Jæger-Waldau, A.; Jones, C.; Keller, A.; Leccisi, E.; Mancarella, P.; Pearsall, N.; Siegel, A.; Sinke, W.; Stolz, P. Energy Return on Energy Invested (ERoEI) for photovoltaic solar systems in regions of moderate insolation: A comprehensive response. Energy Policy 2017, 102, 377-384.

86) Liu, X.; Hoekman, S. K.; Broch, A. Potential water requirements of increased ethanol fuel in the USA. Energy, Sustainability and Society 2017, 7 (1), 18.

87) Zhuo, L.; Mekonnen, M. M.; Hoekstra, A. Y. Sensitivity and uncertainty in crop water footprint accounting: a case study for the Yellow River basin. Hydrol. Earth Syst. Sci. 2014, 18 (6), 2219-2234.

88) Bodirsky, B. L.; Müller, C. Robust relationship between yields and nitrogen inputs indicates three ways to reduce nitrogen pollution. Environ. Res. Lett. 2014, 9 (11), 111005.

89) Chukalla, A. D.; Krol, M. S.; Hoekstra, A. Y. Grey water footprint reduction in irrigated crop production: effect of nitrogen application rate, nitrogen form, tillage practice and irrigation strategy. Hydrol. Earth Syst. Sci. 2018, 22 (6), 3245-3259.

90) Eisentraut, A. Sustainable Production of Second-Generation Biofuels: Potential and Perspectives in Major Economies and Developing Countries; International Energy Agency: Paris, 2010.

91) Liska, A. J.; Yang, H.; Milner, M.; Goddard, S.; Blanco-Canqui, H.; Pelton, M. P.; Fang, X. X.; Zhu, H.; Suyker, A. E. Biofuels from crop residue can reduce soil carbon and increase $\mathrm{CO}_{2}$ emissions. Nat. Clim. Change 2014, 4, 398-401. 


\section{Supporting Information for}

Water, Energy, and Carbon Footprints of Bio-ethanol from the US and Brazil

Mesfin M. Mekonnen ${ }^{1 *}$, Thiago L. Romanelli ${ }^{2}$, Chittaranjan Ray ${ }^{3}$, Arjen Y. Hoekstra ${ }^{4,5}$, Adam J. Liska ${ }^{6}$, Christopher Neale ${ }^{1,6}$

${ }^{1}$ Robert B. Daugherty Water for Food Global Institute, University of Nebraska, Lincoln, NE 68583, USA.

2 Department of Biosystems Engineering, College of Agriculture "Luiz de Queiroz" (ESALQ), University of São Paulo.

${ }^{3}$ Nebraska Water Center, Robert B. Daugherty Water for Food Global Institute, University of Nebraska, Lincoln, NE 68583, USA.

${ }^{4}$ Twente Water Centre, University of Twente, P.O. Box 217, 7500 AE Enschede, The Netherlands

${ }^{5}$ Institute of Water Policy, Lee Kuan Yew School of Public Policy, National University of Singapore, 469A Bukit Timah Road, 259770, Singapore.

${ }^{6}$ Department of Biological Systems Engineering, University of Nebraska, Lincoln, NE 68583, USA.

*Corresponding author: Phone: +1-402-472-5392; e-mail: mmekonnen2@unl.edu.

Content: 7 pages, 8 tables 
Table S1. Inputs in the production of ethanol from corn in the main 9 states (2014-2016 average)

\begin{tabular}{|c|c|c|c|c|c|c|c|c|c|c|c|}
\hline Inputs & Unit & Illinois & Indiana & lowa & Michigan & Minnesota & Nebraska & Ohio & $\begin{array}{r}\text { South } \\
\text { Dakota }\end{array}$ & Wisconsin & $\begin{array}{r}\text { weighted } \\
\text { avg. }\end{array}$ \\
\hline Seed & $\mathrm{kg} / \mathrm{Mg}$ of corn & 2.38 & 2.72 & 2.43 & 2.67 & 2.52 & 2.07 & 2.76 & 2.47 & 2.61 & 2.45 \\
\hline \multicolumn{12}{|l|}{ Fertilizer } \\
\hline Phosphate & $\mathrm{kg} / \mathrm{Mg}$ of corn & 8.01 & 5.86 & 6.40 & 4.07 & 5.33 & 3.26 & 6.74 & 4.87 & 3.17 & 5.74 \\
\hline Potash & $\mathrm{kg} / \mathrm{Mg}$ of corn & 9.83 & 10.41 & 7.99 & 7.81 & 7.32 & 1.73 & 10.03 & 4.58 & 5.43 & 7.26 \\
\hline Sulfur & $\mathrm{kg} / \mathrm{Mg}$ of corn & 1.92 & 1.15 & 1.50 & 1.17 & 1.59 & 1.09 & 1.48 & 1.32 & 1.45 & 1.48 \\
\hline Fungicide & $\mathrm{kg} / \mathrm{Mg}$ of corn & 0.006 & 0.006 & 0.006 & 0.011 & 0.000 & 0.011 & 0.006 & 0.000 & 0.000 & 0.005 \\
\hline Herbicide & $\mathrm{kg} / \mathrm{Mg}$ of corn & 0.038 & 0.058 & 0.040 & 0.055 & 0.046 & 0.044 & 0.055 & 0.053 & 0.051 & 0.045 \\
\hline Insecticide & $\mathrm{kg} / \mathrm{Mg}$ of corn & 0.005 & 0.035 & 0.005 & 0.080 & 0.048 & 0.007 & 0.074 & 0.063 & 0.030 & 0.024 \\
\hline \multicolumn{12}{|l|}{ Energy inputs } \\
\hline Diesel & $\mathrm{L} / \mathrm{Mg}$ of corn & 3.56 & 3.81 & 2.96 & 3.51 & 3.50 & 8.21 & 3.44 & 2.72 & 3.71 & 4.08 \\
\hline Gasoline & L/Mg of corn & 1.41 & 2.03 & 1.39 & 2.13 & 1.56 & 1.84 & 2.06 & 1.67 & 1.46 & 1.62 \\
\hline LPG & $\mathrm{kg} / \mathrm{Mg}$ of corn & 0.77 & 0.54 & 0.55 & 0.92 & 1.17 & 0.56 & 1.55 & 0.77 & 0.86 & 0.76 \\
\hline Electricity & $\mathrm{kWh} / \mathrm{Mg}$ of corn & 1.07 & 0.84 & 1.61 & 1.09 & 1.07 & 23.60 & 1.92 & 2.06 & 0.77 & 4.70 \\
\hline Limestone & $\mathrm{kg} / \mathrm{Mg}$ of corn & 67.41 & 85.81 & 42.99 & 62.48 & 39.84 & 19.77 & 59.18 & 0.00 & 73.08 & 47.37 \\
\hline
\end{tabular}

Seed rate, fertilizer and agrochemicals input are from USDA ${ }^{1}$, Energy, limestone inputs, and crop transport based on Gallagher et al ${ }^{2}$

Table S2. Inputs in the production of bioethanol from sugarcane in the main 6 states (2014-2016 average)

\begin{tabular}{|c|c|c|c|c|c|c|c|c|}
\hline Inputs & Unit & Goiás & $\begin{array}{r}\text { Mato } \\
\text { Grosso }\end{array}$ & $\begin{array}{l}\text { Minas } \\
\text { Gerais }\end{array}$ & Paraná & $\begin{array}{r}\text { Mato } \\
\text { Grosso do } \\
\text { Sul } \\
\end{array}$ & São Paulo & weighted avg. Note \\
\hline Seed & $\mathrm{kg} / \mathrm{Mg}$ of sugarcane & 31.86 & 31.86 & 31.86 & 31.86 & 31.86 & 31.86 & 31.86 Assumed same rate \\
\hline Nitrogen & $\mathrm{kg} / \mathrm{Mg}$ of sugarcane & 1.14 & 1.14 & 1.22 & 1.52 & 1.14 & 1.22 & $\begin{array}{l}\text { 1.10 Fertilizer derived by combining regional } \\
\text { data from } \mathrm{FAO}^{3} \text { a state level yield from }\end{array}$ \\
\hline Phosphate & $\mathrm{kg} / \mathrm{Mg}$ of sugarcane & 0.34 & 0.34 & 0.33 & 0.26 & 0.34 & 0.33 & $0.29 \mathrm{UNICA}^{4}$, and average application rate \\
\hline \multicolumn{9}{|l|}{ Agrochemicals $^{b}$} \\
\hline Fungicide & $\mathrm{g} / \mathrm{Mg}$ of sugarcane & 0.01 & 0.01 & 0.01 & 0.01 & 0.01 & 0.01 & 0.01 Agrochemicals per state derived \\
\hline Herbicide & $\mathrm{g} / \mathrm{Mg}$ of sugarcane & 17.70 & 22.21 & 19.57 & 20.30 & 18.26 & 19.93 & $\begin{array}{l}\text { 19.61 Tam tne average application in } \\
\text { Tand sugarcane yield per }\end{array}$ \\
\hline Insecticide & $\mathrm{g} / \mathrm{Mg}$ of sugarcane & 0.30 & 0.24 & 0.28 & 0.27 & 0.30 & 0.27 & 0.27 state \\
\hline \multicolumn{9}{|l|}{ Energy inputs ${ }^{b}$} \\
\hline Diesel & MJ/Mg of sugarcane & 47.2 & 59.2 & 52.2 & 54.1 & 49.6 & 53.2 & 53.9 Total energy from AgraFNP ${ }^{5}$ \\
\hline Gasoline & $\mathrm{MJ} / \mathrm{Mg}$ of sugarcane & 15.2 & 19.0 & 16.8 & 17.4 & 15.9 & 17.1 & 17.3 combined with GREET model \\
\hline Natural gas & $\mathrm{MJ} / \mathrm{Mg}$ of sugarcane & 26.5 & 33.3 & 29.3 & 30.4 & 27.8 & 29.8 & 30.3 average energy from Table 1 and \\
\hline Electricity & $\mathrm{MJ} / \mathrm{Mg}$ of sugarcane & 11.2 & 14.1 & 12.4 & 12.9 & 11.8 & 12.6 & $\begin{array}{l}12.8 \text { state level sugarcane yield } \\
\text { Derived by combining value from }\end{array}$ \\
\hline Limestone & $\mathrm{kg} / \mathrm{Mg}$ of sugarcane & 8.24 & 10.34 & 9.12 & 9.45 & 8.50 & 9.28 & 9.13 Table 1 and crop yield \\
\hline
\end{tabular}


Table S3. Blue and green water footprint of ethanol production from corn in the main 9 states (2014-2016 average)

\begin{tabular}{|c|c|c|c|c|c|c|c|c|c|c|c|}
\hline & Inputs & Illinois & Indiana & lowa & Michigan & Minnesota & Nebraska & Ohio & $\begin{array}{r}\text { South } \\
\text { Dakota }\end{array}$ & Wisconsin & $\begin{array}{r}\text { weighted } \\
\text { avg. }\end{array}$ \\
\hline \multirow{17}{*}{$\begin{array}{l}\text { Blue water footprint (L/Mg of } \\
\text { corn) }\end{array}$} & Fertilizer & & & & & & & & & & \\
\hline & Nitrogen & 12.07 & 11.32 & 12.57 & 8.88 & 12.28 & 9.20 & 12.03 & 12.76 & 8.29 & 11.48 \\
\hline & Phosphate & 3.62 & 2.65 & 2.89 & 1.84 & 2.41 & 1.47 & 3.05 & 2.20 & 1.43 & 2.60 \\
\hline & Potash & 0.02 & 0.03 & 0.02 & 0.02 & 0.02 & 0.00 & 0.02 & 0.01 & 0.01 & 0.02 \\
\hline & Sulfur & 0.00 & 0.00 & 0.00 & 0.00 & 0.00 & 0.00 & 0.00 & 0.00 & 0.00 & 0.00 \\
\hline & Fungicide & 0.02 & 0.02 & 0.02 & 0.03 & 0.00 & 0.03 & 0.02 & 0.00 & 0.00 & 0.02 \\
\hline & Herbicide & 0.11 & 0.17 & 0.12 & 0.16 & 0.13 & 0.13 & 0.16 & 0.15 & 0.15 & 0.13 \\
\hline & Insecticide & 0.01 & 0.10 & 0.01 & 0.24 & 0.14 & 0.02 & 0.22 & 0.18 & 0.09 & 0.07 \\
\hline & Energy inputs & & & & & & & & & & \\
\hline & Diesel & 7.84 & 8.38 & 6.50 & 7.72 & 7.70 & 18.06 & 7.57 & 5.99 & 8.17 & 8.98 \\
\hline & Gasoline & 3.05 & 4.42 & 3.01 & 4.63 & 3.39 & 3.99 & 4.47 & 3.63 & 3.17 & 3.51 \\
\hline & LPG & 1.91 & 1.36 & 1.36 & 2.29 & 2.91 & 1.40 & 3.88 & 1.91 & 2.15 & 1.91 \\
\hline & Electricity & 7.16 & 5.65 & 10.80 & 7.30 & 7.16 & 158.32 & 12.91 & 13.83 & 5.17 & 31.55 \\
\hline & Limestone & 5627 & 7163 & 3589 & 5216 & 3325 & 1650 & 4940 & 0 & 6100 & 3954 \\
\hline & Seed & 8.09 & 14.71 & 2.66 & 34.34 & 8.21 & 345.19 & 0.47 & 28.79 & 7.65 & 69.88 \\
\hline & Crop blue water footprint & 3394 & 5409 & 1093 & 12857 & 3253 & 166458 & 169 & 11641 & 2932 & 28534 \\
\hline & Total (L/Mg of corn) & 9065 & 12621 & 4722 & 18140 & 6622 & 168646 & 5154 & 11711 & 9069 & 32619 \\
\hline \multirow[t]{5}{*}{ Blue WF (L/L ethanol) } & (L/L of ethanol) & 21.34 & 29.71 & 11.12 & 42.71 & 15.59 & 397.05 & 12.13 & 27.57 & 21.35 & 76.80 \\
\hline & Water input in ethanol plant & 2.70 & 2.70 & 2.70 & 2.70 & 2.70 & 2.70 & 2.70 & 2.70 & 2.70 & 2.70 \\
\hline & Total blue WF & 24.04 & 32.41 & 13.82 & 45.41 & 18.29 & 399.75 & 14.83 & 30.27 & 24.05 & 79.50 \\
\hline & WF credit to co-product & 6.50 & 8.76 & 3.73 & 12.27 & 4.94 & 108.04 & 4.01 & 8.18 & 6.50 & 21.49 \\
\hline & WF allocated to Ethanol & 17.54 & 23.65 & 10.08 & 33.13 & 13.35 & 291.71 & 10.82 & 22.09 & 17.55 & 58.01 \\
\hline \multirow[t]{3}{*}{ Green WF (L/t corn) } & Seed green WF & 870 & 1137 & 888 & 1160 & 986 & 802 & 1236 & 1003 & 1024 & 947 \\
\hline & Crop green WF & 364893 & 418158 & 365214 & 434510 & 390779 & 386972 & 447048 & 405804 & 392490 & 386767 \\
\hline & Total & 365763 & 419295 & 366102 & 435670 & 391765 & 387774 & 448283 & 406808 & 393514 & 387714 \\
\hline \multirow[t]{2}{*}{ Green WF (L/L ethanol) } & Total green WF & 861 & 987 & 862 & 1026 & 922 & 913 & 1055 & 958 & 926 & 913 \\
\hline & Water credit to co-product & 405 & 465 & 406 & 483 & 434 & 430 & 497 & 451 & 436 & 430 \\
\hline \multirow{2}{*}{ Total WF (L/L ethanol) } & Credit to co-product & 412 & 473 & 409 & 495 & 439 & 538 & 501 & 459 & 442 & 451 \\
\hline & WF of ethanol & 473 & 546 & 466 & 576 & 502 & 775 & 570 & 529 & 508 & 541 \\
\hline
\end{tabular}


Table S4. Energy footprint of US corn bioethanol per state (kJ/L) (2014-2016 average)

\begin{tabular}{|c|c|c|c|c|c|c|c|c|c|c|c|}
\hline & Inputs & Illinois & Indiana & lowa & Michigan & Minnesota & Nebraska & Ohio & $\begin{array}{r}\text { South } \\
\text { Dakota }\end{array}$ & Wisconsin & $\begin{array}{r}\text { weighted } \\
\text { avg. }\end{array}$ \\
\hline \multirow[t]{5}{*}{ Fertilizer } & Nitrogen & 1112 & 1019 & 1112 & 800 & 1112 & 829 & 1112 & 1112 & 748 & 1019 \\
\hline & Phosphoric Acid (P2O5) & 391 & 286 & 312 & 199 & 260 & 159 & 329 & 238 & 155 & 280 \\
\hline & Calcium Carbonate $(\mathrm{CaCO} 3)$ & 22 & 28 & 14 & 20 & 13 & 6 & 19 & 0 & 24 & 15 \\
\hline & Herbicides & 23 & 35 & 24 & 33 & 28 & 26 & 33 & 32 & 31 & 27 \\
\hline & Insecticides & 3 & 25 & 3 & 57 & 34 & 5 & 53 & 45 & 0 & 17 \\
\hline & Gasoline blendstock & 133 & 193 & 132 & 202 & 148 & 175 & 195 & 159 & 139 & 154 \\
\hline & Natural gas & 11 & 26 & 6 & 75 & 6 & 48 & 54 & 0 & 39 & 21 \\
\hline & Liquified Petroleum Gas & 25 & 18 & 18 & 30 & 38 & 18 & 51 & 25 & 28 & 25 \\
\hline & Electricity & 16 & 13 & 25 & 17 & 16 & 361 & 29 & 32 & 12 & 72 \\
\hline & Corn transport to ethanol plar & 598 & 556 & 487 & 606 & 530 & 539 & 607 & 505 & 547 & 534 \\
\hline & Energy input in Ethanol plant & 9239 & 9239 & 9239 & 9239 & 9239 & 9239 & 9240 & 9239 & 9239 & 9239 \\
\hline & Total energy input & 12116 & 12014 & 11818 & 11778 & 11914 & 12271 & 12253 & 11746 & 11437 & 11951 \\
\hline & $\begin{array}{l}\text { Net energy input } \\
\text { Energy output in the form of }\end{array}$ & 10251 & 10167 & 10010 & 9984 & 10090 & 10366 & 10358 & 9950 & 9714 & 10114 \\
\hline & ethanol & 21274 & 21274 & 21274 & 21274 & 21274 & 21274 & 21274 & 21274 & 21274 & 21274 \\
\hline & Energy balance & 11023 & 11107 & 11264 & 11290 & 11184 & 10908 & 10916 & 11324 & 11560 & 11160 \\
\hline & Energy Ratio & 2.08 & 2.09 & 2.13 & 2.13 & 2.11 & 2.05 & 2.05 & 2.14 & 2.19 & 2.10 \\
\hline
\end{tabular}

Summerized from GREET model run

Table S5. Carbon footprint of US corn bioethanol per input and per state ( $\left.\mathrm{g} \mathrm{CO}_{2} \mathrm{eq} / \mathrm{MJ}\right)(2014-2016$ average)

\begin{tabular}{|c|c|c|c|c|c|c|c|c|c|c|c|}
\hline & Inputs & Illinois & Indiana & lowa & Michigan & Minnesota & Nebraska & Ohio & $\begin{array}{r}\text { South } \\
\text { Dakota }\end{array}$ & Wisconsin & $\begin{array}{r}\text { weighted } \\
\text { avg. }\end{array}$ \\
\hline \multirow[t]{5}{*}{ Fertilizer } & Nitrogen & 9.32 & 8.71 & 9.71 & 6.88 & 9.49 & 7.10 & 9.32 & 9.88 & 6.40 & 8.88 \\
\hline & Phosphoric Acid $\left(\mathrm{P}_{2} \mathrm{O}_{5}\right)$ & 1.31 & 0.96 & 1.05 & 0.65 & 0.87 & 0.52 & 1.09 & 0.78 & 0.52 & 0.91 \\
\hline & Calcium Carbonate $\left(\mathrm{CaCO}_{3}\right)$ & 1.70 & 2.18 & 1.09 & 1.57 & 1.00 & 0.48 & 1.48 & 1.00 & 1.83 & 1.18 \\
\hline & Herbicides & 0.09 & 0.13 & 0.09 & 0.12 & 0.10 & 0.10 & 0.12 & 0.12 & 0.11 & 0.10 \\
\hline & Insecticides & 0.01 & 0.09 & 0.01 & 0.20 & 0.12 & 0.02 & 0.19 & 0.16 & 0.00 & 0.06 \\
\hline & Gasoline blendstock & 0.48 & 0.70 & 0.48 & 0.74 & 0.52 & 0.61 & 0.70 & 0.57 & 0.48 & 0.57 \\
\hline & Natural gas & 0.04 & 0.09 & 0.02 & 0.25 & 0.02 & 0.16 & 0.18 & 0.00 & 0.13 & 0.07 \\
\hline & Liquified Petroleum Gas & 0.08 & 0.06 & 0.06 & 0.10 & 0.13 & 0.06 & 0.17 & 0.08 & 0.09 & 0.08 \\
\hline & Electricity & 0.06 & 0.05 & 0.10 & 0.07 & 0.06 & 1.44 & 0.12 & 0.12 & 0.05 & 0.28 \\
\hline & $\mathrm{N}_{2} \mathrm{O}$ emission & 3.15 & 3.15 & 3.15 & 3.15 & 3.15 & 3.15 & 3.15 & 3.15 & 3.15 & 3.15 \\
\hline & Corn transport & 2.15 & 2.01 & 1.77 & 2.21 & 1.91 & 1.96 & 2.21 & 1.82 & 1.98 & 1.94 \\
\hline & Ethanol production & 29.88 & 29.88 & 29.88 & 29.88 & 29.88 & 29.88 & 29.88 & 29.88 & 29.87 & 29.88 \\
\hline & Credit to DGS (Displaced Res & -12.45 & -12.32 & -12.08 & -11.83 & -12.08 & -12.08 & -12.45 & -11.83 & -11.58 & -12.08 \\
\hline & Total emission & 45.7 & 45.6 & 44.8 & 43.7 & 44.8 & 44.4 & 45.9 & 44.9 & 42.6 & 44.9 \\
\hline
\end{tabular}

Summerized from GREET model run 
Table S6. Blue and green water footprint of bioethanol production from Brazilian sugarcane in the main 6 states (2014-2016 average)

\begin{tabular}{|c|c|c|c|c|c|c|c|c|}
\hline & Inputs & Goiás & $\begin{array}{r}\text { Mato } \\
\text { Grosso }\end{array}$ & $\begin{array}{l}\text { Minas } \\
\text { Gerais }\end{array}$ & Paraná & $\begin{array}{r}\text { Mato } \\
\text { Grosso do } \\
\text { Sul } \\
\end{array}$ & São Paulo & weighted avg. \\
\hline \multirow{17}{*}{$\begin{array}{l}\text { Blue water footprint (L/Mg of } \\
\text { sugarcane) }\end{array}$} & Fertilizer & & & & & & & \\
\hline & Nitrogen & 1.81 & 1.81 & 1.94 & 2.42 & 1.81 & 1.94 & 1.75 \\
\hline & Phosphate & 0.16 & 0.16 & 0.15 & 0.12 & 0.16 & 0.15 & 0.13 \\
\hline & Potash & 0.004 & 0.004 & 0.003 & 0.003 & 0.004 & 0.003 & 0.003 \\
\hline & Agrochemicals & & & & & & & \\
\hline & Herbicide & 0.052 & 0.065 & 0.057 & 0.059 & 0.053 & 0.058 & 0.057 \\
\hline & Insecticide & 0.001 & 0.001 & 0.001 & 0.001 & 0.001 & 0.001 & 0.001 \\
\hline & Energy inputs & & & & & & & \\
\hline & Diesel & 2.99 & 3.75 & 3.31 & 3.43 & 3.08 & 3.37 & 3.31 \\
\hline & Gasoline & 1.05 & 1.31 & 1.16 & 1.20 & 1.08 & 1.18 & 1.16 \\
\hline & LPG & 4.94 & 6.20 & 5.47 & 5.67 & 5.10 & 5.57 & 5.48 \\
\hline & Natural gas & 0.06 & 0.08 & 0.07 & 0.07 & 0.06 & 0.07 & 0.07 \\
\hline & Electricity & 21.55 & 27.04 & 23.83 & 24.71 & 22.23 & 24.26 & 23.86 \\
\hline & Limestone & 688 & 863 & 761 & 789 & 710 & 775 & 762 \\
\hline & Seed & 263 & 8 & 148 & 23 & 232 & 100 & 125 \\
\hline & Crop blue water footprint & 8269 & 247 & 4654 & 725 & 7291 & 3132 & 3934 \\
\hline & Total (L/Mg of sugarcane) & 9259 & 1167 & 5606 & 1582 & 8274 & 4050 & 4865 \\
\hline \multirow[t]{5}{*}{ Blue WF (L/L ethanol) } & (L/L of ethanol) & 107 & 14 & 65 & 18 & 96 & 47 & 56 \\
\hline & Water input in ethanol plant & 19 & 19 & 19 & 19 & 19 & 19 & 19 \\
\hline & Total blue WF & 127 & 33 & 84 & 38 & 115 & 66 & 76 \\
\hline & WF credit to co-product & 16 & 4 & 11 & 5 & 15 & 9 & 10 \\
\hline & WF allocated to Ethanol & 110 & 29 & 74 & 33 & 101 & 58 & 66 \\
\hline \multirow[t]{3}{*}{ Green WF (L/Mg sugarcane) } & Seed green WF & 2610 & 3646 & 2804 & 3996 & 3687 & 3216 & 3208 \\
\hline & Crop green WF & 81927 & 114461 & 88020 & 125446 & 115719 & 100951 & 100701 \\
\hline & Total & 84537 & 118107 & 90824 & 129442 & 119406 & 104167 & 103909 \\
\hline \multirow[t]{3}{*}{ Green WF (L/L ethanol) } & Total green WF & 980 & 1369 & 1052 & 1500 & 1384 & 1207 & 1204 \\
\hline & Water credit to co-product & 126 & 176 & 135 & 193 & 178 & 155 & 155 \\
\hline & Allocated to ethanol & 854 & 1193 & 917 & 1307 & 1206 & 1052 & 1049 \\
\hline \multirow[t]{3}{*}{ Total WF (L/L ethanol) } & Green + blue WF & 1106 & 1402 & 1137 & 1538 & 1499 & 1273 & 1280 \\
\hline & Credit to co-product & 142 & 180 & 146 & 198 & 193 & 164 & 165 \\
\hline & WF of ethanol & 964 & 1221 & 991 & 1340 & 1306 & 1110 & 1115 \\
\hline
\end{tabular}


Table S7. Energy footprint of Brazilian sugarcane bioethanol per state $(\mathrm{kJ} / \mathrm{L})$

\begin{tabular}{|c|c|c|c|c|c|c|c|c|}
\hline & Item & Goiás & $\begin{array}{r}\text { Mato } \\
\text { Grosso }\end{array}$ & $\begin{array}{l}\text { Minas } \\
\text { Gerais }\end{array}$ & Paraná & $\begin{array}{r}\text { Mato } \\
\text { Grosso do } \\
\text { Sul } \\
\end{array}$ & São Paulo & weighted avg. \\
\hline \multirow[t]{6}{*}{ Fertilizer } & Nitrogen & 802 & 802 & 860 & 1081 & 802 & 860 & 779 \\
\hline & Phosphoric Acid $\left(\mathrm{P}_{2} \mathrm{O}_{5}\right)$ & 30 & 35 & 33 & 26 & 35 & 33 & 30 \\
\hline & Potassium Oxide & 80 & 95 & 86 & 82 & 95 & 86 & 80 \\
\hline & Calcium Carbonate $\left(\mathrm{CaCO}_{3}\right)$ & 25 & 27 & 24 & 25 & 23 & 24 & 25 \\
\hline & Herbicides & 49 & 54 & 47 & 49 & 44 & 47 & 49 \\
\hline & Insecticides & 0.77 & 0.72 & 0.80 & 0.77 & 0.86 & 0.80 & 0.77 \\
\hline \multirow[t]{5}{*}{ Farming } & Diesel for non Road applicatic & 756 & 826 & 733 & 756 & 698 & 744 & 756 \\
\hline & Gasoline blendstock & 244 & 279 & 244 & 256 & 233 & 244 & 244 \\
\hline & Natural gas & 384 & 430 & 372 & 395 & 360 & 384 & 384 \\
\hline & Liquified Petroleum Gas & 349 & 384 & 337 & 349 & 326 & 337 & 349 \\
\hline & Electricity & 67 & 74 & 65 & 67 & 62 & 66 & 67 \\
\hline Transport & Cane transport & 404 & 404 & 404 & 404 & 404 & 405 & 404 \\
\hline Ethanol plant & Ethanol production & 373 & 373 & 374 & 374 & 373 & 373 & 373 \\
\hline \multirow[t]{4}{*}{ Total } & Total energy input & 3541 & 3784 & 3580 & 3866 & 3456 & 3605 & 3541 \\
\hline & Energy output in the form of $\epsilon$ & 21274 & 21274 & 21274 & 21274 & 21274 & 21274 & 21274 \\
\hline & Energy balance & 17733 & 17490 & 17694 & 17408 & 17818 & 17669 & 17733 \\
\hline & Energy Ratio & 6.01 & 5.62 & 5.94 & 5.50 & 6.16 & 5.90 & 6.01 \\
\hline
\end{tabular}

Summerized from GREET model run

Table S8. Carbon footprint of Brazilian sugarcane bioethanol per state (g CO ${ }_{2}$ eq/MJ) (2014-2016 average)

\begin{tabular}{|c|c|c|c|c|c|c|c|c|}
\hline & Item & Goiás & $\begin{array}{r}\text { Mato } \\
\text { Grosso }\end{array}$ & $\begin{array}{l}\text { Minas } \\
\text { Gerais }\end{array}$ & Paraná & $\begin{array}{r}\text { Mato } \\
\text { Grosso do } \\
\text { Sul } \\
\end{array}$ & São Paulo & weighted avg. \\
\hline \multirow[t]{6}{*}{ Fertilizer } & Nitrogen & 6.8 & 6.8 & 7.3 & 9.1 & 6.8 & 7.3 & 6.6 \\
\hline & Phosphoric Acid $\left(\mathrm{P}_{2} \mathrm{O}_{5}\right)$ & 0.1 & 0.1 & 0.1 & 0.1 & 0.1 & 0.1 & 0.1 \\
\hline & Potassium Oxide & 0.3 & 0.3 & 0.3 & 0.3 & 0.3 & 0.3 & 0.3 \\
\hline & Calcium Carbonate $\left(\mathrm{CaCO}_{3}\right)$ & 1.0 & 1.3 & 1.1 & 1.2 & 1.1 & 1.2 & 1.2 \\
\hline & Herbicides & 0.1 & 0.2 & 0.2 & 0.2 & 0.2 & 0.2 & 0.2 \\
\hline & Insecticides & 0.0 & 0.0 & 0.0 & 0.0 & 0.0 & 0.0 & 0.0 \\
\hline \multirow[t]{12}{*}{ Farming } & Diesel for non Road applicatic & 2.4 & 3.0 & 2.7 & 2.7 & 2.5 & 2.7 & 2.7 \\
\hline & Gasoline blendstock & 0.8 & 1.0 & 0.9 & 0.9 & 0.8 & 0.9 & 0.9 \\
\hline & Natural gas & 1.1 & 1.4 & 1.3 & 1.3 & 1.2 & 1.3 & 1.3 \\
\hline & Liquified Petroleum Gas & 1.0 & 1.3 & 1.1 & 1.2 & 1.1 & 1.1 & 1.1 \\
\hline & Electricity & 0.2 & 0.3 & 0.2 & 0.2 & 0.2 & 0.2 & 0.2 \\
\hline & Straw burning & 1.0 & 1.0 & 1.0 & 1.0 & 1.0 & 1.0 & 1.0 \\
\hline & Vinasse transportation & 2.0 & 2.0 & 2.0 & 2.0 & 2.0 & 2.0 & 2.0 \\
\hline & Above/below ground $\mathrm{N}_{2} \mathrm{O}$ & 0.0 & 0.0 & 0.0 & 0.0 & 0.0 & 0.0 & 0.0 \\
\hline & Cane transport & 1.5 & 1.5 & 1.5 & 1.5 & 1.5 & 1.5 & 1.5 \\
\hline & Ethanol production & 3.5 & 3.5 & 3.5 & 3.5 & 3.5 & 3.5 & 3.5 \\
\hline & Land use change & 16.0 & 16.0 & 16.0 & 16.0 & 16.0 & 16.0 & 16.0 \\
\hline & Total emission & 37.9 & 39.6 & 39.0 & 41.1 & 38.2 & 39.2 & 38.5 \\
\hline
\end{tabular}

Summerized from GREET model run 
References

1. USDA, Agricultural Statistics Data Base (Quick Stats). U.S. Department of Agriculture, National Agricultural Statistics Service (USDA-NASS): Washington, DC, 2017.

2. Gallagher, P. W.; Yee, W. C.; Baumes, H. S. 2015 Energy Balance for the Corn-Ethanol Industry; U.S. Department of Agriculture, Office of the Chief Economist, Office of Energy Policy and New Uses: Washington, DC, 2016

3. FAO Fertilizer use by crop in Brazil; Food and Agriculture Organization (FAO): Rome, Italy, 2004.

4. UNICA (Brazilian Sugarcane Industry Association) UNICA Data Center. http://www.unicadata.com.br/historico-de-producao-emoagem.php?idMn=32\&tipoHistorico=4 (accessed 20 September 2018).

5. AgraFNP Agrianual Yearbook of Brazilian Agriculture (in Portuguese) ; AgraFNP Consultoria e Comércio: São Paulo, Brazil, 2015. 